\title{
Agro-ecological functions of crop residues under conservation agriculture. A review
}

\author{
Lalaina Ranaivoson ${ }^{1,2}$ - Krishna Naudin ${ }^{2,3}$ • Aude Ripoche ${ }^{2,4}$ - François Affholder ${ }^{2}$. \\ Lilia Rabeharisoa $^{5}$ - Marc Corbeels ${ }^{2,6}$
}

Accepted: 2 June 2017 / Published online: 18 July 2017

(C) INRA and Springer-Verlag France SAS 2017

\begin{abstract}
Conservation agriculture, which is based on minimum tillage, permanent soil cover and crop rotations, has widely been promoted as a practice to maintain or improve soil quality and enhance crop productivity. To a large extent, the beneficial effects of conservation agriculture are expected to be provided by permanent soil cover with crop residues. Surface crop residues play an important role for crop growth through their benefits on soil-related structural components and processes in the agro-ecosystem, referred to in this study as agro-ecological functions. Through a meta-analysis of the literature, we have studied the relative effects of surface crop residue levels on the performance of a set of agro-ecological functions compared with a no-till bare soil, i.e., without surface residues. The selected agro-ecological functions were soil water evaporation control, soil water infiltration, soil water
\end{abstract}

Lalaina Ranaivoson

lalainabakotiana@yahoo.fr

1 Centre national de recherche appliquée au développement rural (FOFIFA), Route d'Andraisoro, 101, BP

1690 Antananarivo, Madagascar

2 Agro-ecology and Sustainable Intensification of Annual Crops, Centre de Coopération Internationale en Recherche Agronomique pour le Développement (CIRAD), Av. Agropolis, 34060 Montpellier, France

3 Embrapa Cerrados, Rodovia BR-020, Km 18 Caixa Postal: 08223, Planaltina, DF 73310-970, Brazil

4 SRR FOFIFA, BP 230, Antsirabe, Madagascar

5 Laboratoire des Radio-Isotopes (LRI), Université d'Antananarivo, BP 3383, 101, Antananarivo, Madagascar

6 Sustainable Intensification Program, International Maize and Wheat Improvement Center (CIMMYT), P.O. Box 1041-00621,

Nairobi, Gigiri, Kenya runoff control, soil loss control, soil nutrient availability, soil organic carbon (SOC) stocks and gains, weed control and soil meso- and macrofauna abundance. The potential effects of crop residue cover were quantified using boundary line models. Our main findings were (1) $8 \mathrm{t} \mathrm{ha}^{-1}$ of residues were needed to decrease soil water evaporation by about $30 \%$ compared to no-till bare soil. (2) To achieve the maximum effect on soil water infiltration, water runoff and soil loss control, residue amounts of at least $2 \mathrm{t} \mathrm{ha}^{-1}$ were required. (3) The effect of increasing the amounts of surface crop residues on soil nutrient supply (N, P and K) was relatively low; the boundary line models were not significant. (4) The average annual SOC gain increased with increasing amounts of residues, with a mean of $0.38 \mathrm{tC} \mathrm{ha}^{-1}$ year $^{-1}$ with 4 to $5 \mathrm{tha}^{-1}$ of residues. (5) Weed emergence and biomass can be reduced by $50 \%$ compared to a no-till bare soil with residue amounts of $1 \mathrm{t} \mathrm{ha}^{-1}$ or more. (6) There was a weak response in soil mesoand macrofauna abundance to increasing amounts of surface crop residues. The maximum effect corresponded to an increase of $45 \%$ compared to a no-till bare soil and was reached from $10 \mathrm{tha}^{-1}$ of residues. Our findings suggest that optimal amounts of surface residues in the practice of conservation agriculture will largely depend on the type of constraints to crop production which can be addressed with mulching.

Keywords Mulch · Soil water evaporation · Soil water infiltration · Runoff · Erosion · Soil nutrient supply · Soil organic carbon $\cdot$ Weed $\cdot$ Mesofauna $\cdot$ Macrofauna . Conservation tillage $\cdot$ Meta-analysis

\section{Contents}

1. Introduction

2. Material and methods

3. Results and discussion 
3.1. Effect of surface crop residues on soil water processes 3.1.1. Soil water evaporation

3.1.2. Soil water infiltration

3.1.3. Soil water runoff

3.2. Effect of surface crop residues on soil erosion

3.3. Effect of surface crop residues on soil nutrient availability

3.3.1. Soil mineral nitrogen

3.3.2. Available soil phosphorus

3.3.3. Exchangeable soil potassium

3.4. Effect of surface crop residues on soil organic carbon

3.5. Effect of surface crop residues on weed infestation

3.5.1 Weed emergence

3.5.2 Weed biomass

3.6. Effect of surface crop residues on soil meso- and macrofauna abundance

3.7. Maximum effects of crop residue cover

4. Conclusions

Acknowledgments

References

\section{Introduction}

Soil degradation, defined as negative changes in a soil's organic matter and nutrient status, is a worldwide problem. It has emerged as a threat to food security through the reduction in crop production (Oldeman 1998). Practical solutions for soil conservation are needed to ensure sustainable food production. Conservation agriculture has widely been promoted as a practice to maintain or improve soil quality and enhance crop productivity (Scopel et al. 2013). Conservation agriculture is based on three principles: minimum soil disturbance, permanent soil cover and crop rotations (FAO 2015). Previous studies have stated that increases in crop productivity using conservation agriculture are to a large extent provided by the permanent soil cover (e.g., Hobbs 2007).

Crop residues retained as mulch on the soil have effects on the soil-related structural components and processes of the agro-ecosystem (see Fig. 1), potentially enhancing crop production. In this study, we denote these components or processes as agro-ecological functions.

Mulching with crop residues limits soil water evaporation and soil crusting, thereby increasing soil water infiltration and soil water availability to the crop (e.g., Scopel et al. 2004; Gangwar et al. 2006). Residue cover provides physical soil protection from water runoff and minimizes the risks of water and wind erosion (e.g., Bertol et al. 2007; Lal 2009). Decomposition of crop residues retained on the soil surface also influences nutrient cycling in the soil and the availability of nutrients to the crop (Aulakh et al. 1991; Govaerts et al. 2007; Turmel et al. 2014). Finally, minimum soil disturbance and the presence of a residue cover may enhance soil carbon storage (Corbeels et al. 2006), contribute to the reduction of weed infestation (Teasdale and Mohler 2000; CaamalMaldonado et al. 2001; Bilalis et al. 2003) and increase soil biological activity (Kladivko 2001; Liu et al. 2016).

The effects of surface crop residues vary according to climate conditions, and factors such as residue level and type of residue can influence crop responses to mulching. Some authors have reported low or delayed germination rates and reduced crop growth with high quantities of crop residues under cool and humid climates (e.g., Schneider and Gupta 1985; Swanson and Wilhelm 1996). Several studies have found that additional nitrogen $(\mathrm{N})$ fertilizer is needed when cereal crop residues are left on soils to avoid an immobilization of soil mineral $\mathrm{N}$ resulting in lower crop yields (e.g., Beri et al. 1995; Govaerts et al. 2006).

Crop residues have uses other than mulch, such as for livestock feed (Giller et al. 2009; Naudin et al. 2012) or for biofuel production (Wilhelm 2004; Lal 2009). Using crop residues as livestock feed can result in greater economic benefits than their retention as mulch for the improvement of soil fertility (Naudin et al. 2012). One megagram of maize residues is equivalent to about 3781 of ethanol (Lal 2009). So, there are clearly competing uses for crop residues between energy production, livestock feed and agro-ecological functions. This implies that trade-offs exist in their use. Evaluating the performance of surface crop residues in relation to a set of agroecological functions can therefore indicate which crop residue management is best and what amounts are optimal.

The aim of this paper is to identify relationships between soil cover using crop residues and the performance of selected agro-ecological functions. To achieve this, the performance of agro-ecological functions on no-till mulched soils was compared with that of no-till bare soils (Fig. 2), i.e., without surface residues, through a systematic literature review. Such a comprehensive review has not been conducted before.

The agro-ecological functions provided by surface crop residues that were analyzed in this study were soil water evaporation control, soil water infiltration, soil water runoff control, soil loss control, soil nutrient availability (mineral N, available phosphorus $(\mathrm{P})$, exchangeable potassium $(\mathrm{K})$ ), soil organic carbon (SOC) stocks and gains, weed control (weed emergence, weed biomass) and meso- and macrofauna abundance. The performance of each function was analyzed both according to the amount of residue and the proportion of soil covered by residue.

\section{Material and methods}

\subsection{Literature search}

We performed a systematic literature search according to the PRISMA (Preferred Reporting Items for Systematic Reviews 


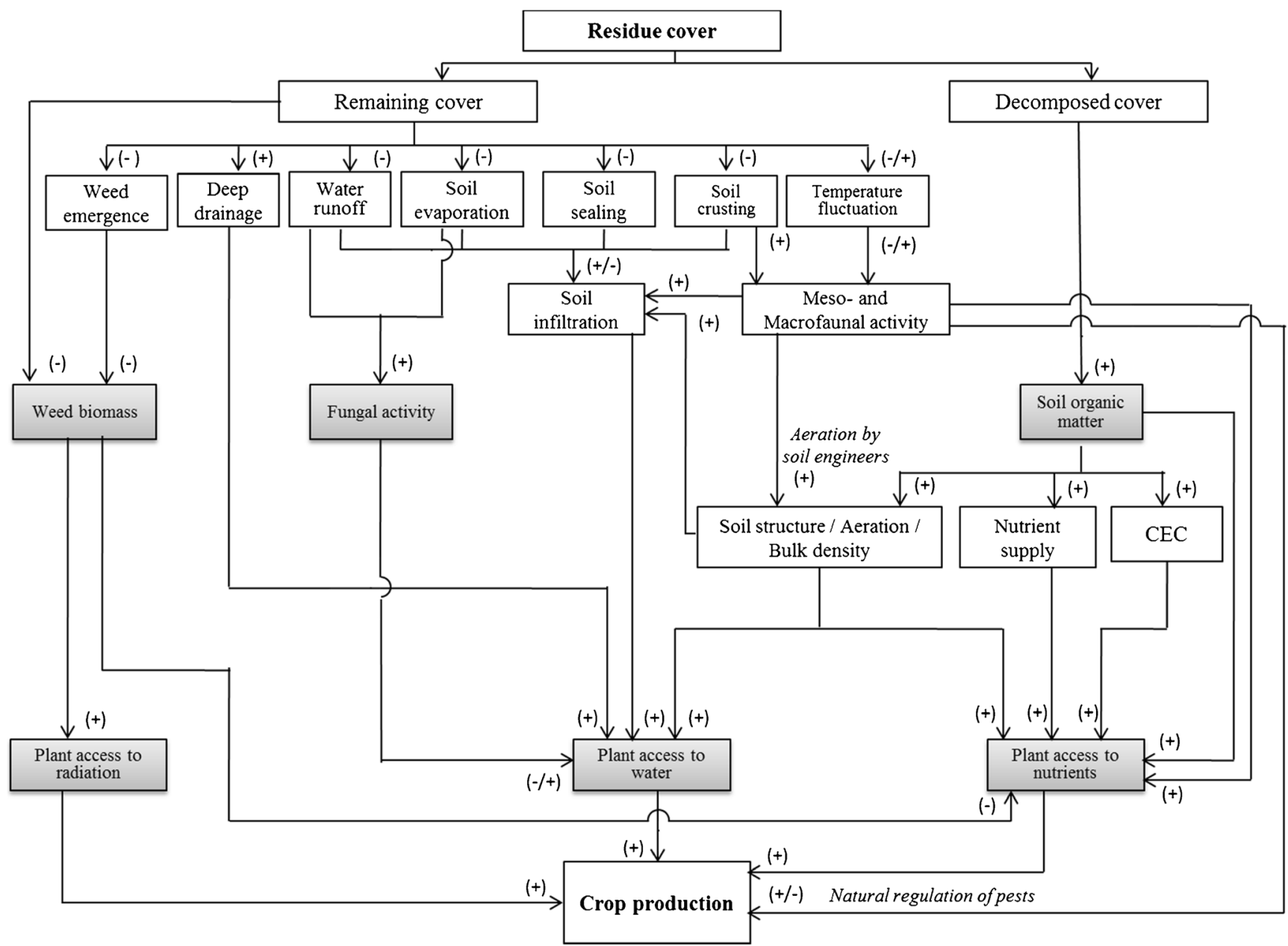

Fig. 1 Agro-ecological functions of surface crop residues. (+) and (-) signs designate positive and negative effects, respectively, adapted from Lu et al. (2000) and Turmel et al. (2014)

and Meta-Analyses) statement (Moher et al. 2009). The on-line Scopus database (http://www.scopus.com) was used for the literature search. The subject area was limited to Agricultural and Biological Sciences, the search language to English and the combination of keywords varied according to the agroecological function being studied. For all searches, the following keywords were used (an asterisk being a replacement for any ending of the respective term): [mulch* OR residu* OR straw] AND ['Conservation Agriculture' OR 'no till*' OR 'zero till*' OR 'direct seeding' OR 'direct drilling' OR DMC]. DMC is the acronym for direct seeding mulchbased cropping, another denomination for conservation
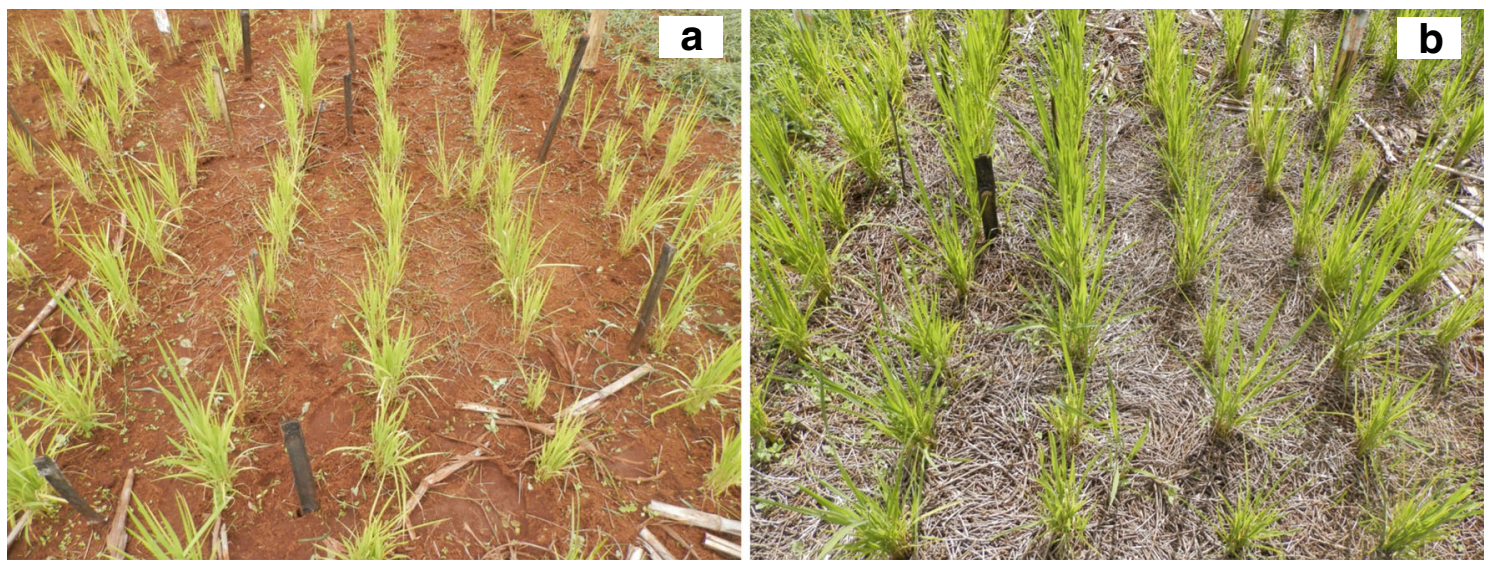

Fig. 2 Rice crop under no-till practice on bare soil (a) and with a mulch of Stylosanthes guianensis residues (b), Madagascar (photo by L. Ranaivoson) 
agriculture. These keywords were combined with [evaporation], [infiltration], [runoff*], [erosion], ['inorganic nitrogen' OR 'soil nitrogen supply' OR 'nitrogen availability' OR 'mineral nitrogen'], [phosphorus OR phosphorous], [potassium], [carbon], [weed], [*fauna OR termit* OR earthworm OR nematode* OR spider* OR centiped* OR staphylinid* OR ant* OR slug*] for studying the effects of surface crop residues on, respectively, soil water evaporation, soil water infiltration, water runoff, soil erosion, mineral nitrogen, available phosphorus, exchangeable potassium, weed infestation and soil mesoand macrofauna abundance.

\subsection{Study selection}

Publications were eligible for inclusion if data on the selected agro-ecological functions was available from field experiments in which a no-till bare soil treatment, i.e., without crop residues, was compared with a no-till soil treatment using a mulch of crop residues. Taking this approach, the sole effect of surface crop residues on agro-ecological functions could be investigated, without the interactive effects of (no-)tillage. Studies from the selected publications compared bare soil and mulched soil treatments using randomized block designs or paired comparison designs with repetitions. The results in our analysis were expressed relative to no-till bare soil, thus allowing for the aggregation and analysis of data from studies conducted under different agro-ecological conditions. This approach also allowed us to compare the different agroecological functions that are provided by residue cover. Publications which did not report the quantities of surface crop residues or the extent of soil cover provided by crop residues used in the experiments were excluded. We also excluded publications involving residues from perennial crops, plastic mulch or live mulch. Data from model simulations was not used in the analysis, however published models which show a relationship between the quantity of mulch and an agro-ecological function were presented. Studies from the same publication that were conducted under different experimental conditions or treatments (e.g., slope, fertilization and cropping season) were considered as individual cases in this review. In total, 54 papers were considered in our analysis, representing a total of 110 study cases.

\subsection{Data extraction}

For each study, we extracted data that were available in the text, tables or figures on the agro-ecological functions under study in our review. Numerical values were extracted from figures by using WebPlotDigitizer 3.8. (Rohatgi 2015). Study cases were classified as tropical or temperate according to the Köppen climate classification (Peel et al. 2007). From the 110 study cases, $56 \%$ were from tropical regions and $44 \%$ from temperate regions. The study cases included several types of mulch: $34 \%$ used maize residues, $20 \%$ used wheat residues and $20 \%$ used rice residues.

\subsection{Data analysis}

For each agro-ecological function, results were analyzed both according to the amount of surface residue and the proportion of soil covered by residue. When the soil cover was not available, the quantity of crop residues (M) was converted to the proportion of soil covered $\left(F_{\mathrm{c}}\right)$ following the equation described in Gregory (1982):

$\mathrm{F}_{\mathrm{c}}=1-\mathrm{e}^{-\mathrm{Am} * \mathrm{M}}$,

where the coefficient $A_{\mathrm{m}}$ is the area-to-mass ratio of the residue (ha $\mathrm{kg}^{-1}$ ). Values for $A_{\mathrm{m}}$ were taken from Steiner et al. (2000) for wheat, oat, barley and rye residues; Dickey et al. (1985) for soybean, pea, cowpea, pigeon pea and oil radish residues; Gregory (1982) for maize and sorghum residues; Anzalone et al. (2010) for rice and Bahiagrass residues; Macena Da Silva et al. (2006) for millet residues and Teasdale and Mohler (2000) for vetch and lupine residues. $M$ is the amount of residue $\left(\mathrm{kg} \mathrm{ha}^{-1}\right)$. The reverse was conducted when the proportion of soil covered by residues was available, but no data on the quantity of residues was available in the published study.

The performance by which an agro-ecological function is provided by surface crop residues for functions which normally have positive impacts on crop production, namely soil water infiltration, soil nutrient availability, SOC stocks and mesoand macrofauna abundance, was defined as (Törnqvist et al. 1985):

$(\mathrm{Ym}-\mathrm{Yb}) / \mathrm{Yb}$,

where $\mathrm{Ym}$ and $\mathrm{Yb}$ are the values of the function considered on mulched ( $m$ subscript) and bare soil ( $b$ subscript) respectively. Using the same naming convention, for soil water evaporation, water runoff, soil loss, weed emergence and weed biomass, which normally have a negative impact on crop production, performance was defined as:

$(\mathrm{Yb}-\mathrm{Ym}) / \mathrm{Yb}$,

For each agro-ecological function, we reported both discrete values and continuous functions from the publications selected for this review.

Boundary line models, as the maximum response for each function in relation to the amount of surface residues, were drawn. They represent the best performance of surface residues with respect to a given agro-ecological function across the studies in this review. These boundary lines were fitted by using the maximum likelihood methodology (Milne et al. 2006). The boundary line models were evaluated using the 
index of agreement (IOA) based on Willmott et al. (2012), which spans between -1 and +1 , with values approaching +1 representing better model performance. Exponential models were the best fit for all agro-ecological functions. The parameters of each boundary line model are detailed in Table 1.

\section{Results and discussion}

\subsection{Effect of surface crop residues on soil water processes}

We analyzed the effect of quantity and cover of surface crop residues on three major soil water processes affecting the crop water balance, i.e., soil water evaporation, soil water infiltration and water runoff.

\subsubsection{Soil water evaporation}

Four cases, from Balwinder-Singh et al. (2011) and Gava et al. (2013), were retrieved from the literature measuring soil water evaporation under no-till soil with and without a mulch of crop residues. All these studies were conducted in tropical regions.

Total soil water evaporation during the cropping season was reduced by crop residue mulches (Fig. 3). The maximum effect of the quantity of surface residues on soil water evaporation as shown by the boundary line was a reduction of close to $30 \%$ compared to bare soil, which is reached with $8 \mathrm{tha}^{-1}$ of residues or more (Fig. 3a). Parameter estimates of the boundary line were highly significant $(P<0.001)$, despite the low number of observations. There was a general trend of decreasing soil water evaporation with increasing proportions of soil covered by residues (Fig. 3b).

Surface crop residues provide physical soil protection and reduce the solar energy reaching the soil, thereby reducing soil water evaporation losses (Scopel et al. 2004; Lal 2008; Balwinder-Singh et al. 2011). A mulch of crop residues is more effective in reducing soil water evaporation when the soil is wet and the leaf areas of growing crops are low (Lal 2008; Balwinder-Singh et al. 2011), which explains the differences in effects on soil water evaporation during the pre- versus post-anthesis period of wheat observed by BalwinderSingh et al. (2011).

\subsubsection{Soil water infiltration}

The data published on the effect of increasing amounts of surface residues on soil water infiltration was highly dispersed (Fig. 3c, d). The majority of studies were from tropical zones. The boundary line showed a twofold increase in soil water infiltration compared to bare soil with $2 \mathrm{t} \mathrm{ha}^{-1}$ of residues or more. Parameter estimates of the boundary line were significant $(P<0.05)$ (Fig. 3c). There was a general trend of an increase in the soil water infiltration rate with an increasing proportion of soil covered by residues (Fig. 3d). A totally covered soil can increase soil water infiltration fourfold compared to bare soil.

Residue cover intercepts part of the rainfall, limiting soil crusting and soil losses through runoff, and thereby increasing the soil water infiltration rate (Lal 2008). Residues and the products of their decomposition improve soil structure

Table 1 Parameters of the boundary lines fitted in this study

\begin{tabular}{|c|c|c|c|c|c|c|}
\hline Agro-ecological function & Regression model & Estimate, a & $\begin{array}{l}\text { Significance test } \\
\text { of the parameter } \\
\text { estimate }^{(1)}\end{array}$ & $\begin{array}{l}\text { Confidence interval } \\
\text { of parameter estimate } \\
(95 \%)\end{array}$ & $r^{2}$ & IOA \\
\hline Soil water evaporation control & $y \sim(1.30 /(1+0.30 \times \exp .(-a \times x)))-1$ & 0.344 & $* * *$ & $0.256 ; 0.430$ & 0.98 & 0.94 \\
\hline Soil water infiltration & $y \sim(2.14 /(1+1.14 \times \exp .(-a \times x)))-1$ & 1.402 & $*$ & $0.413 ; 2.391$ & 0.97 & 0.95 \\
\hline Water runoff control & $y \sim(1.96 /(1+0.96 \times \exp .(-a \times x)))-1$ & 1.405 & $*$ & $0.473 ; 2.337$ & 0.85 & 0.82 \\
\hline Soil erosion control & $y \sim(1.96 /(1+0.96 \times \exp .(-a \times x)))-1$ & 2.702 & $* * *$ & $1.861 ; 3.543$ & 0.99 & 0.97 \\
\hline Soil mineral nitrogen & $y \sim(1.32 /(1+0.32 \times \exp .(-a \times x)))-1$ & 1.184 & NS & $-0.017 ; 2.385$ & 0.94 & 0.91 \\
\hline Available soil phosphorus & $y \sim(1.30 /(1+0.30 \times \exp .(-a \times x)))-1$ & 0.867 & NS & $-0.264 ; 1.998$ & 0.96 & 0.90 \\
\hline Exchangeable soil potassium & $y \sim(1.17 /(1+0.17 \times \exp .(-a \times x)))-1$ & 0.600 & NS & - & - & - \\
\hline SOC stock & $y \sim(2.09 /(1+1.09 \times \exp .(-a \times x)))-1$ & 0.187 & $* *$ & $0.109 ; 0.264$ & 0.84 & 0.82 \\
\hline Annual gain of SOC & $y \sim(2.75 /(1+1.75 \times \exp .(-a \times x)))-1$ & 0.313 & $* * *$ & $0.228 ; 0.399$ & 0.91 & 0.86 \\
\hline Weed emergence control & $y \sim(1.99 /(1+0.99 \times \exp .(-a \times x)))-1$ & 1.156 & $* * *$ & $0.767 ; 1.543$ & 0.86 & 0.84 \\
\hline Weed biomass control & $y \sim(1.95 /(1+0.95 \times \exp .(-a \times x)))-1$ & 1.075 & $* *$ & $0.626 ; 1.524$ & 0.96 & 0.93 \\
\hline $\begin{array}{l}\text { Meso- and macrofauna } \\
\text { abundance }\end{array}$ & $y \sim(1.47 /(1+0.47 \times \exp .(-a \times x)))-1$ & 0.295 & $* *$ & $0.199 ; 0.390$ & 0.99 & 0.95 \\
\hline
\end{tabular}

$x$ amount of residues, $y$ agro-ecological function performance, IOA index of agreement, SOC soil organic carbon, NS not significant

(1) $* * * P<0.001 ; * * P<0.01 ; * P<0.05$ 
through enhanced soil aggregate stability and soil porosity (Jordán et al. 2010), which also improves the soil water infiltration rate. The negative effects of residue cover on soil water infiltration, as shown in some case studies from BlancoCanqui and Lal (2007a, 2009), could be explained by the fact that the presence of mulch may restrict water infiltration by imparting water repellent and hydrophobic properties to the soil surface (Sharratt et al. 2006).

It is important to note that the relationship between soil water infiltration and surface residues also depends on several other factors, such as slope, soil hydraulic conductivity, vegetation density, and rainfall quantity and intensity (Dunne et al. 1991; TerAvest et al. 2015). Blanco-Canqui and Lal $(2007 \mathrm{a}, 2009)$ reported that water infiltration increased with increasing levels of soil cover on a slope of $10 \%$, while on a slope of less than $2 \%$, water infiltration was not related to the level of soil cover. Such interactions between factors involved in soil water infiltration processes make it unlikely that a clear relationship between soil water infiltration and mulch quantity or cover can be defined. We were unable to account for these factors as, for example, co-variates because of the limited information available on these factors in the selected papers. Nevertheless, since we compared soil water infiltration rates between bare and mulched soils under the same (no-till) soil conditions, it can be expected that the major effects on water infiltration are the result of residue cover and its effect on soil structure (Verhulst et al. 2010).

\subsubsection{Soil water runoff}

The efficiency by which surface residues control water runoff increased with the amount of residue. The spread of observations on soil water runoff as a function of residue mulch was lower when related to the quantity of residues than to the proportion of soil covered (Fig. 3e, f). Residue amounts of 1.5 to $4.5 \mathrm{t}$ dry matter ha ${ }^{-1}$ decreased water runoff by about $50 \%$ compared to bare soil (Fig. 3e). Parameter estimates of the boundary line were significant $(P<0.05)$. The equation from Scopel et al. (2004) for soil cover suggests that the same effect can be reached with a soil cover of about 20\% (Fig. 3f).

Surface crop residues protect soil against structural degradation of the surface, thereby increasing rainfall infiltration and reducing water runoff. Residue cover delays the time before runoff is initiated and slows runoff flows as a result of the increased roughness of the soil surface and the obstruction of runoff pathways (Lal 1997).

For an equal amount of surface residue, significant differences in efficiency on water runoff can to a great extent be explained by the level of the slope of the field (Scopel et al. 2005 ) and by the amount and intensity of rainfall (Dunne et al. 1991). Results from Scopel et al. (2005) showed that $4.5 \mathrm{t}$ dry matter ha ${ }^{-1}$ of surface residues reduced runoff by 20 and $40 \%$ compared to bare soil on slopes of 3 and $7 \%$, respectively.
Findeling et al. (2003) and Scopel et al. (2005) showed that $1.5 \mathrm{t}$ dry matter ha ${ }^{-1}$ of residues reduced water runoff by $50 \%$ compared to bare soil when the total rainfall was less than $40 \mathrm{~mm}$, while with rainfall of more than $1000 \mathrm{~mm}, 4.5 \mathrm{tha}^{-1}$ of residues was needed to achieve the same effect.

\subsection{Effect of surface crop residues on soil erosion}

Soil erosion decreased drastically with increasing amounts of surface crop residues (Fig. 4). Residue levels of 2 to 4 t dry matter ha ${ }^{-1}$ reduced soil erosion by about $80 \%$ compared to bare soil. With $8 \mathrm{t}$ dry matter ha ${ }^{-1}$ of residues and above, there is virtually no more soil loss. Examining the level of soil cover, around $60 \%$ soil cover reduced soil loss by an average of $80 \%$. The boundary line showed that the maximum effect of surface residue amounts on soil erosion can be reached with $2 \mathrm{t} \mathrm{ha}^{-1}$ of residues (Fig. 4a). This corresponds to $80 \%$ soil cover or more (Fig. 4b). Parameter estimates of the boundary line were highly significant $(P<0.001)$.

Residue cover dissipates raindrop energy and reduces the velocity of runoff flows, thereby decreasing soil detachment (Mannering and Meyer 1963; Gilley et al. 1986). It protects the physical structure of topsoil, improves aggregate stability and minimizes surface crusting (Jordán et al. 2010).

The efficiency of residue cover in reducing soil loss depends to a great extent on rainfall intensity (Lal 1997; Scopel et al. 2005). Results from Scopel et al. (2005) show that $4.5 \mathrm{t}$ dry matter ha ${ }^{-1}$ reduced soil erosion by $36 \%$ compared to bare soil during a stormy year, whereas the same quantity of residues reduced soil erosion by only $16 \%$ compared to bare soil in years with low rainfall intensity. This effect may also explain the differences between results from experiments with simulated and real rainfall events; residue cover was in general more effective under simulated rainfall having, on average, higher rainfall intensities than real rainfall events (Fig. 4a, b).

The efficiency of residue cover in soil erosion control also depends on the type of residue. Wheat residues, which have a higher area-to-mass ratio than maize, rye or rice residues, are the most effective for soil erosion control. For maize, rye and rice residues, amounts between 1.5 and $4.5 \mathrm{t}$ dry matter ha ${ }^{-1}$ were needed to reduce soil loss by $50 \%$ compared to bare soil, while only $2 \mathrm{t}$ dry matter ha ${ }^{-1}$ of wheat residues reduced soil loss by about $90 \%$ (Woyessa and Bennie 2004).

\subsection{Effect of surface crop residues on soil nutrient availability}

Residue decomposition releases nutrients to the soil and increasing amounts of surface residues are expected to improve soil nutrient content, at least in the long term. In the short term ( $<1$ year), an immobilization of nutrients into soil organic matter may occur as a result of the relatively high $\mathrm{C}$-tonutrient ratios of residues such as cereal straw. Data studied 
a

\section{Soil water evaporation control}

$(\mathbf{Y b}-\mathbf{Y m}) / \mathbf{Y b}$

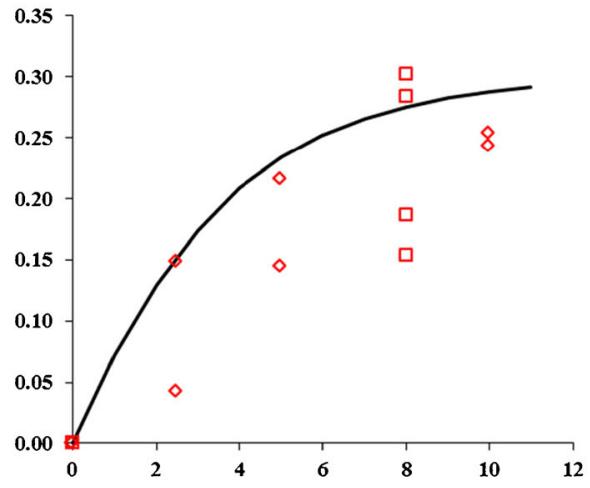

\section{C}

\section{Soil water infiltration}

$(\mathbf{Y m}-\mathbf{Y b}) / \mathbf{Y b}$

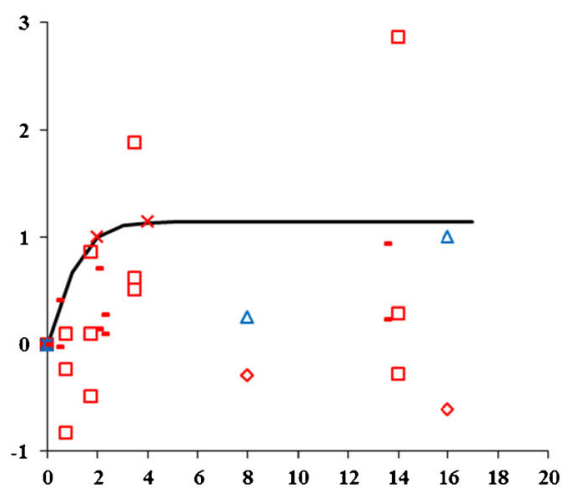

e

Soil water runoff control

$(\mathbf{Y b}-\mathbf{Y m}) / \mathbf{Y b}$

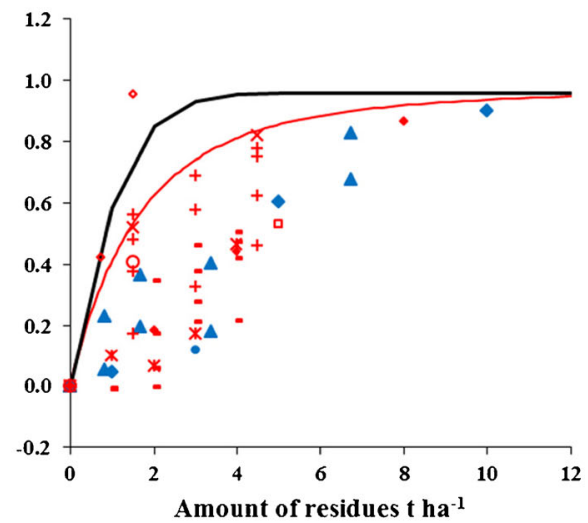

Fig. 3 Relative effect of surface crop residues on soil water evaporation control, soil water infiltration, and soil water runoff control. Blue symbols are data from temperate zones and red symbols from tropical zones. For soil water runoff, filled symbols are data from simulated rainfall and unfilled symbols are from real rainfall events. Black curves are the boundary lines using the maximum likelihood methodology. Red curves are from published literature Data were from Balwinder-Singh et al. 2011, Blanco-
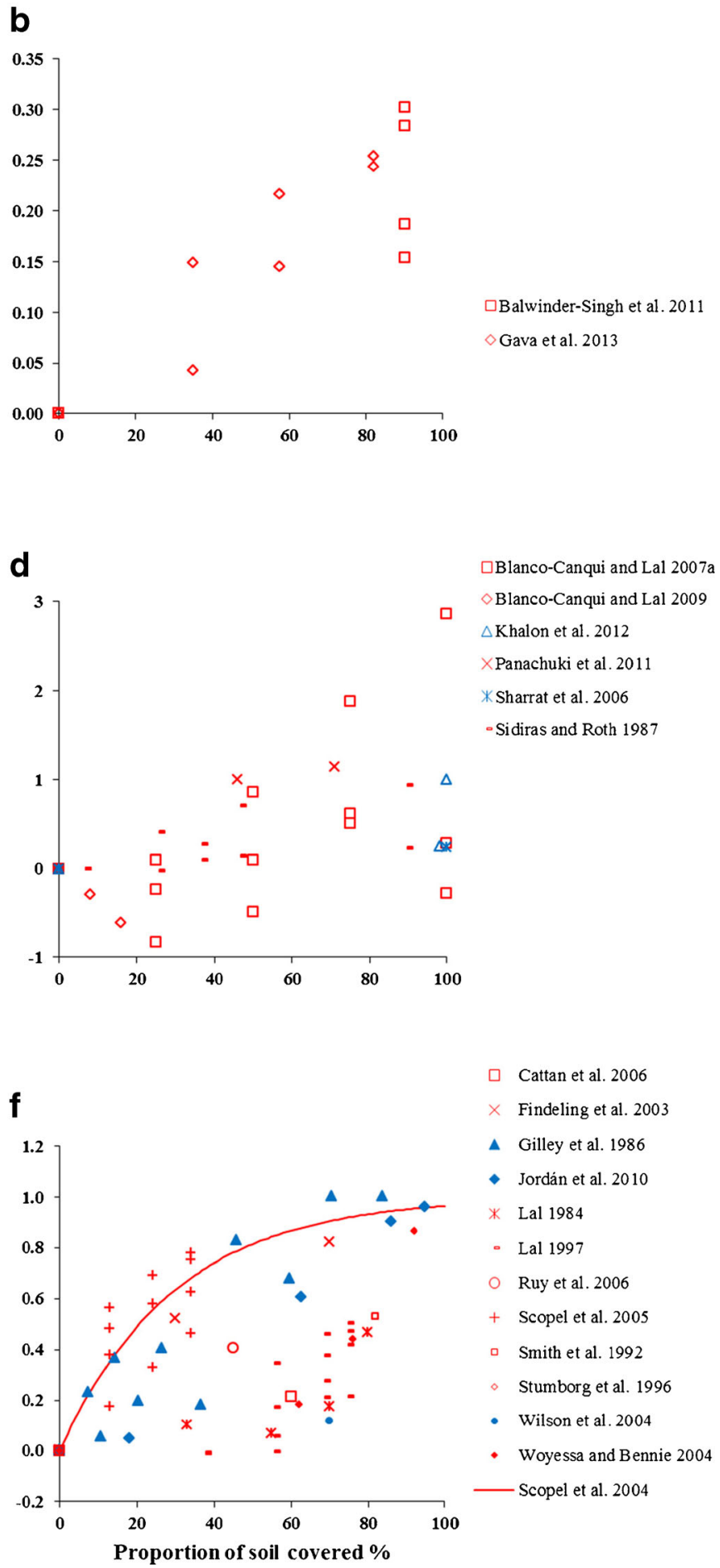

Canqui and Lal 2007a, 2009, Cattan et al. 2006, Findeling et al, 2003, Gava et al. 2013, Gilley et al. 1986, Jordán et al. 2010, Khalon et al. 2012, Lal 1984, 1997, Panachuki et al. 2011, Ruy et al. 2006, Scopel et al. 2004, Scopel et al. 2005, Sharrat et al. 2006, Sidiras and Roth 1987, Smith et al. 1992, Stumborg et al. 1996, Wilson et al. 2004, Woyessa and Bennie 2004. Ym: value of mulch soil, Yb: value of bare soil, see equations 2 and 3 
in this section concerns soil nutrient concentrations $\left(\mathrm{g} \mathrm{kg}^{-1}\right)$ in the $0-30 \mathrm{~cm}$ topsoil layer from studies with time horizons of 1 to 3 years. In this part of the paper, we review the effect of residue cover on soil mineral $\mathrm{N}$, available $\mathrm{P}$ and exchangeable $\mathrm{K}$. Although it is expected that changes in soil bulk density may occur under a no-till bare soil compared to a no-till soil with surface crop residues, especially during the first years of the experiment, the use of nutrient concentrations instead of stocks does not essentially affect the final relationships and conclusions that we found on the effects of surface crop residues on soil nutrient availability. Nutrient contents in no-till soil with surface residues may somewhat have been underestimated as a result of a possible lower soil bulk density compared to no-till bare soil (without residues).

\subsubsection{Soil mineral nitrogen}

Results from the studies reviewed showed a trend of increased mineral $\mathrm{N}$ concentration with increased residue cover. The efficiency of residue cover in improving soil mineral $\mathrm{N}$ concentration was, however, relatively low (Fig. 5a, b). The maximum effect corresponded to an increase of around 30\% compared to bare soil and was reached with more than $10 \mathrm{t}$ dry matter ha ${ }^{-1}$ of residues, which is equivalent to $100 \%$ soil cover. However, in some case studies residue amounts from 4 to $7 \mathrm{t}$ dry matter ha ${ }^{-1}$ caused a decrease in soil mineral $\mathrm{N}$ compared to bare soil without surface residues.

Residue decomposition influences the availability of $\mathrm{N}$ for crops through the release of mineral $\mathrm{N}$ to the soil. Legume residues with a relatively low $\mathrm{C}$-to- $\mathrm{N}$ ratio lead to nitrogen mineralization, whereas cereal residues with a relatively high C-to-N ratio can temporally immobilize N (Aulakh et al. 1991;
Govaerts et al. 2006). As expected, the results from the reviewed papers showed in general a higher increase of soil mineral $\mathrm{N}$ in the case of legume residues than in the case of cereal residues (Fig. 5a, b).

The observed decreases of soil mineral $\mathrm{N}$ concentration in mulched soils compared to bare soils can therefore be explained by the immobilization of $\mathrm{N}$ during the decomposition process of non-legume residues (Feng et al. 2014).

\subsubsection{Available soil phosphorus}

As shown in Fig. 5c, d, observations of available soil $\mathrm{P}$ as a function of the amount of surface residues or the proportion of soil covered were highly dispersed.

Retention of crop residues in the field is expected to increase the availability of $\mathrm{P}$ in topsoil through mineralization, which was demonstrated by the data from Feng et al. (2014) and Pradhan et al. (2011), showing an improvement of available soil $\mathrm{P}$ with an increase in the amount of residue. However, wheat and maize residues in the studies conducted by Iqbal et al. (2011) and Wang et al. (2011) showed a decrease in available $\mathrm{P}$ under mulched soil compared to bare soil. Singh and Jones (1976) found that residues with a P concentration of less than $0.22 \%$ resulted in a net $\mathrm{P}$ immobilization. Moreover, surface residues can affect topsoil $\mathrm{pH}$ (e.g., Lal 1997; Govaerts et al. 2007) which may also have a strong effect on soil $\mathrm{P}$ availability (Sato and Comerford 2005). The possible effects on soil $\mathrm{pH}$ are related to the chemical composition of residues and soil properties. This could be one of the explanations for the spread of observations. It has also been demonstrated that organic compounds released during residue decomposition can increase or decrease a soil's $\mathrm{P}$

\section{a}

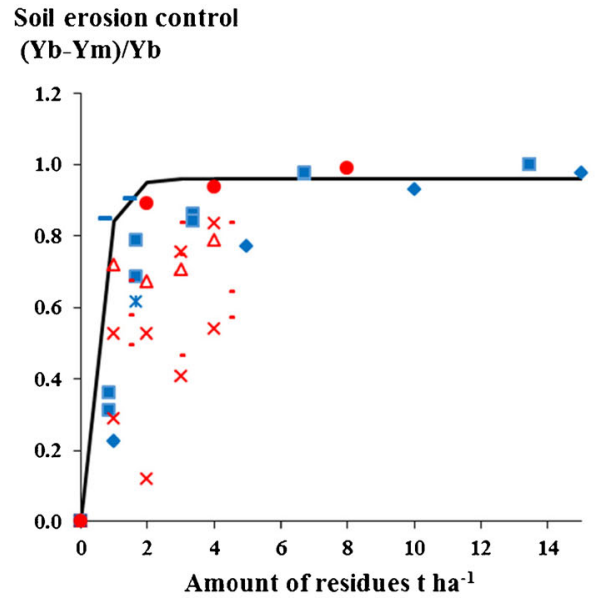

Fig. 4 Relative effect of surface crop residues on soil erosion control. Blue symbols are data from temperate zones and red symbols from tropical zones. Filled symbols are data from simulated rainfall and unfilled symbols are from real rainfall events. The black curve is the boundary line using the maximum likelihood methodology. The red

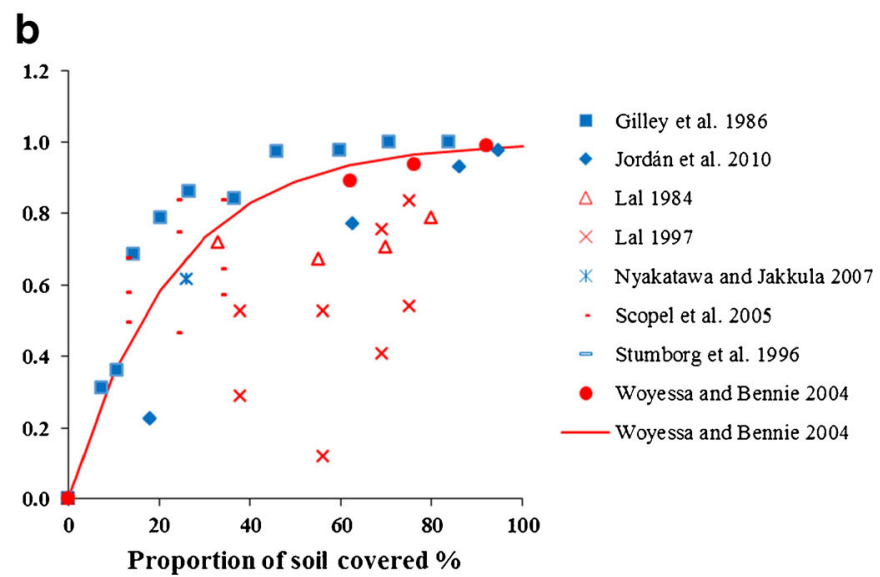

curves are from published literature Data were from Gilley et al. 1986, Jordán et al. 2010, Lal 1984, Lal 1997, Nyakatawa and Jakkula 2007, Scopel et al. 2005, Stumborg et al. 1996, Woyessa and Bennie 2004. Ym: value of mulch soil, $\mathrm{Yb}$ : value of bare soil, see equations 2 and 3 
adsorption capacity, depending on the $\mathrm{P}$ concentration of residues (Haynes and Mokolobate 2001).

\subsubsection{Exchangeable soil potassium}

Surface crop residues increased exchangeable soil K content compared to bare soil (Fig. 5e, f) in the two studies that we retrieved from the literature. According to the observations made in these studies, the efficiency of residue cover in enhancing soil exchangeable $\mathrm{K}$ was more pronounced in a temperate climate than in a tropical climate.

Crop residues are known to be rich in $\mathrm{K}$ and are therefore expected to be an important source of soil $\mathrm{K}$ when retained on the soil (Lupwayi et al. 2006). The efficiency of residue cover in increasing soil exchangeable $\mathrm{K}$ depends to a large extent on the residue's K content. Rosolem et al. (2005) have shown that released $\mathrm{K}$ is correlated to the residue's $\mathrm{K}$ content. Potassium is, however, prone to leaching (Rosolem et al. 2006; Calonego and Rosolem 2013). This could explain the relatively small increase of exchangeable $\mathrm{K}$ in the top soil layers with increased residue levels (Fig. 5e).

\subsection{Effect of surface crop residues on soil organic carbon}

The studies examined in this section reported soil organic carbon (SOC) stocks $\left(\mathrm{t} \mathrm{ha}^{-1}\right)$ in the $0-20 \mathrm{~cm}$ topsoil layer and varied in time between 3 and 28 years. For some cases, SOC stocks were calculated from the reported data on SOC concentration and bulk density. For each study, we also calculated the corresponding average annual SOC storage rate.

Overall, SOC stocks increased with increasing amounts of residues (Fig. 6). According to the boundary line, the maximum increase of SOC stocks compared to bare soil was 50\% with residue amounts of $6 \mathrm{t} \mathrm{ha}^{-1}$. Parameter estimates for the boundary line were highly significant $(P<0.01)$. No relationship was found for the proportion of soil covered by residues (Fig. 6b).

Annual gains of SOC from the selected studies were relatively low, with a mean of $0.50 \mathrm{t} \mathrm{C} \mathrm{ha}^{-1}$ year $^{-1}$ for residue levels of 1.5 to $16 \mathrm{t} \mathrm{ha}^{-1}$. The maximum SOC gain corresponded to $1.75 \mathrm{tC} \mathrm{ha}^{-1}$ year $^{-1}$ with $16 \mathrm{tha}^{-1}$ of residues (Fig. 6c). Parameter estimates for the boundary line were also highly significant $(P<0.001)$.

SOC storage depends mainly on soil texture and structure (Campbell et al. 1996a, b; Lal 2004) which to a large extent explains the variability of results for the same amount of residue. The finer fraction of soil (silt and clay) plays an important role in stabilizing SOC (Lorenz et al. 2008; Jagadamma and Lal 2010). As a result, clay soils will in general have higher SOC stocks than sandy soils. However, we were not able to consider clay or sand content as a co-variable in our analysis because of the limited data; information on soil texture was not always available for the selected studies.
The low response of SOC stocks to residue cover for some of the cases studied could also be due to the high initial SOC content (Rasmussen and Collins 1991). Once steady state SOC levels are reached, annual returns of residues no longer affect SOC stocks (Hooker et al. 2005). This may explain the relatively small increases of SOC stocks in the $>15$-year experiments reported by Hooker et al. (2005) and Lenka and Lal (2013).

\subsection{Effect of surface crop residues on weed infestation}

Surface crop residues are known to have an impact on weed ecology (Chauhan et al. 2012). Residue cover can influence weed emergence and weed biomass by altering soil moisture, light transmittance to the soil surface and the leaves of weed seedlings or through allelopathic effects (Chauhan et al. 2012).

\subsubsection{Weed emergence}

Overall, weed emergence decreased with increasing amounts of residues (Fig. 7a). However, in some cases where mulch rates were less than $7 \mathrm{t}$ dry matter ha ${ }^{-1}$, weed emergence was stimulated compared to bare soil. The quantity of mulch needed to reduce weed emergence by $50 \%$ relative to bare soil varied widely from 1 to $10 \mathrm{t}$ dry matter ha ${ }^{-1}$. The maximum effect, as shown by the boundary line, occurred with residue amounts of $4 \mathrm{t}$ dry matter ha ${ }^{-1}$ or above. Parameter estimates for the boundary line were highly significant $(P<0.001)$. No relationship was found between the proportion of soil covered by crop residues and weed emergence (Fig. 7b).

Surface crop residues create micro-environments that are either inhibitive or favorable to weed germination. Crop residues can interfere with weed establishment either by physically impeding their emergence and altering soil conditions (Teasdale and Mohler 2000; Bilalis et al. 2003), or by exhibiting allelopathic effects which inhibit weed germination (Weston 1996). An increase in soil moisture in the topsoil layer due to the presence of surface crop residues can stimulate weed emergence, particularly under a partially covered soil (Buhler et al. 1996).

The effect of surface residues on weed emergence may also vary according to the rate of residue decomposition (Teasdale and Mohler 2000). Rapid residue decomposition leads to a swift decrease in soil cover and may promote weed emergence by increasing soil fertility. Among other factors, this could explain the variable responses for equal residue amounts (Fig. 7a). For example, the two distinct relationships between weed emergence and the amount of surface residue found by Teasdale and Mohler (2000) during the 1996 and 1997 seasons were in part explained by the faster residue decomposition in 1996 than in 1997. The different responses of weed emergence to residue cover between temperate and tropical climate zones (Fig. 7a, b) can to a certain extent be explained by the effect of climate conditions on the dormancy release of weed populations (Benech-Arnold et al. 2000). 
a

\section{Mineral nitrogen concentration} $(\mathbf{Y m}-\mathbf{Y b}) / \mathbf{Y b}$

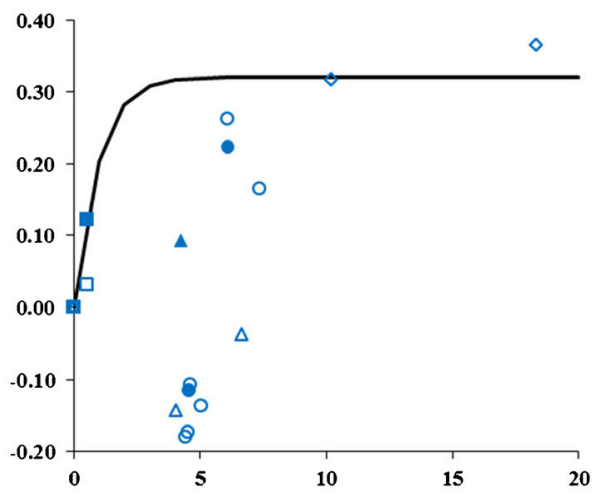

C

Available phosphorus concentration

$(\mathbf{Y m}-\mathbf{Y b}) / \mathbf{Y b}$

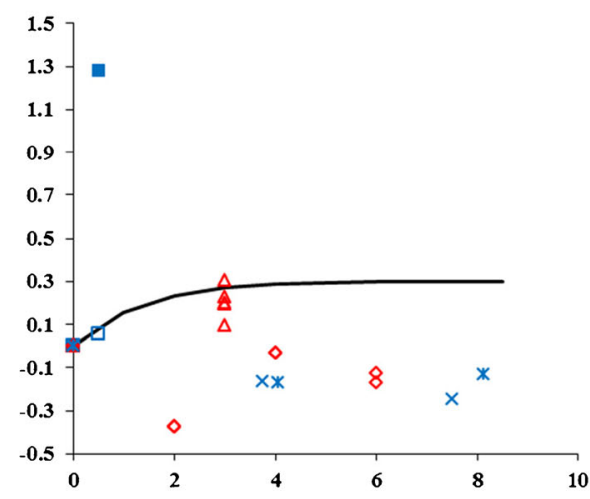

e

Exchangeable potassium concentration

$(\mathbf{Y m}-\mathbf{Y b}) / \mathbf{Y b}$

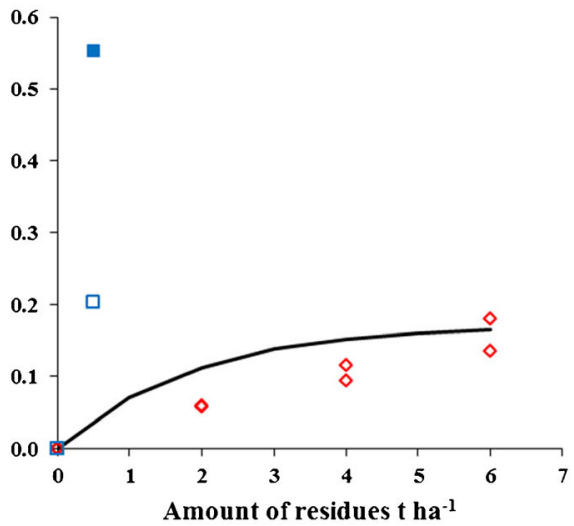

Fig. 5 Relative effect of surface crop residues on soil nutrient availability (N, P, K). Blue symbols are data from temperate zones and red symbols from tropical zones. Filled symbols are data with legume residues and unfilled symbols with cereal and a mixture of cereal and legume residues. Black curves are the boundary lines using the maximum likelihood

d

f
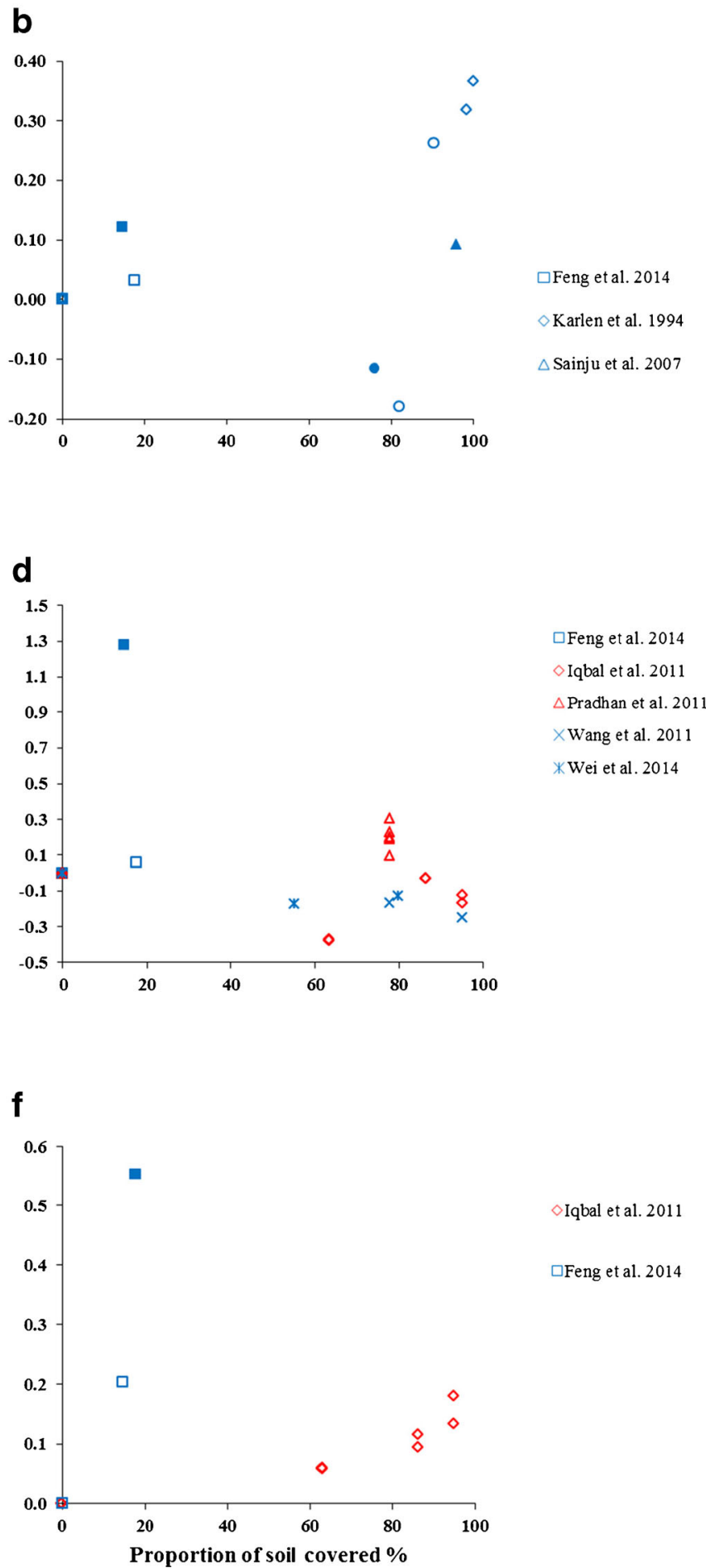

$\diamond$ Iqbal et al. 2011

$\square$ Feng et al. 2014

methodology Data were from Feng et al. 2014, Iqbal et al. 2011, Karlen et al. 1994, Pradhan et al. 2011, Vollmer et al. 2010, Sainju et al. 2007, Wang et al. 2011, Wei et al. 2014. Ym: value of mulch soil, Yb: value of bare soil, see equations 2 and 3 


\section{a}

SOC stock

$(\mathbf{Y m}-\mathbf{Y b}) / \mathbf{Y b}$

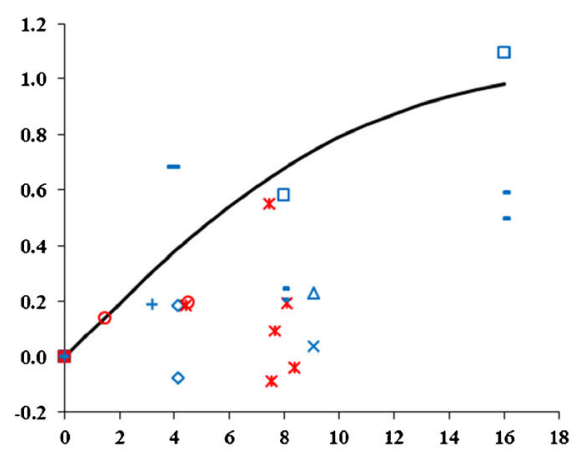

C

Annual gain of $\mathrm{SOC}$ $\left(\mathrm{tha}^{-1}\right.$ year $\left.^{-1}\right)$

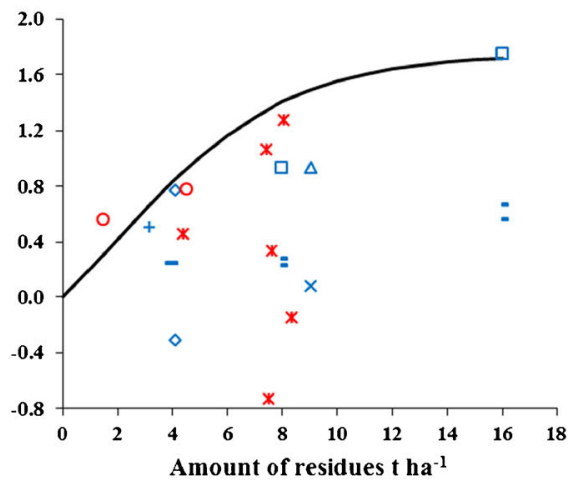

Fig. 6 Relative effect of surface crop residues on SOC stocks and annual SOC gains. Blue symbols are data from temperate zones and red symbols from tropical zones. Black curves are the boundary lines using the maximum likelihood methodology Data were from Blanco-Canqui and

\subsubsection{Weed biomass}

An increase in the amount of surface crop residues limited weed biomass compared to bare soil (Fig. 7c, d). The maximum effect, as shown by the boundary line, occurred with residue amounts of $4 \mathrm{t}$ dry matter ha ${ }^{-1}$ or above. Parameter estimates for the boundary line were significant $(P<0.01)$. No relationship was found between the proportion of soil covered by crop residues and weed biomass (Fig. 7d).

Residues retained on the soil influence light, temperature and moisture conditions of a soil and thereby affect weed biomass (Teasdale and Mohler 1993). Apart from the amount of residue, the efficiency of weed control through mulching also depends on the type of residue and the weed species (Teasdale and Mohler 2000), which could explain the variable responses. For example, results from Mischler et al. (2010), Campiglia et al. (2012) and Radicetti et al. (2013) showed that oat residues had a higher weed suppression capacity than residues from hairy vetch and oilseed rape. Oat residues are known to act as a smother crop for weed control (Zerner et al. 2008). In addition, oat residues have allelopathic effects influencing the germination and growth of weeds (KatoNoguchi et al. 1994). Finally, surface crop residues influence the specific conditions of weed growth, which may influence the species composition and population of weeds (Teasdale et al. 1991). This in turn may affect the weed biomass as a result of weed-specific development and growth rates. To a large extent, this probably explains the different responses of weed biomass to crop residue cover.

\subsection{Effect of surface crop residues on soil meso- and macrofauna abundance}

Soil meso- and macrofauna abundance plays an important role in the soil environment. It has been stated that the application of crop residues is the most effective practice for enhancing soil biodiversity (Liu et al. 2016). Among the eight papers reviewed, one paper studied the nematode community, two 
studied arthropods and five studied earthworms. The results showed that this type of fauna increased with increasing amounts of surface residues (Fig. 8a). However, the increases in soil fauna in relation to increasing amounts of residues were relatively low. With $5 \mathrm{t}$ dry matter $\mathrm{ha}^{-1}$ of surface residues, soil fauna can be increased by a maximum of $30 \%$ compared to bare soil, as shown by the boundary line. Karlen et al. (1994) found that increasing the mulch rate to more than $10 \mathrm{t}$ dry matter $\mathrm{ha}^{-1}$ did not further increase soil fauna, which corresponds to the boundary line fitted in our study. We did not find a clear relationship between the proportion of soil covered by crop residues and soil meso- and macrofauna abundance (Fig. 8b).

Residue cover provides organic matter which is a food source for soil fauna (Stinner 1990; Kladivko 2001). However, the effects vary according to the type of residue, which to a large extent explains the variability in responses to crop residue amounts (Fig. 8a). Some authors have found that the earthworm population was negatively correlated to the $\mathrm{C}$-to-N ratio and polyphenol concentration of residues (Hendriksen 1990; Tian et al. 1993).

The relatively weak response of fauna in soils with surface residues compared to bare soil could also be explained by the fact that the bare reference soils are no-till soils. It is generally known that no-till enhances the diversity of soil fauna and their recovery after conventional tillage (Kladivko 2001; Blanchart et al. 2007; Brévault et al. 2007).

\subsection{Maximum effects of crop residue cover}

The boundary lines for all agro-ecological functions were combined in order to compare the maximum effects of surface residue cover between the agro-ecological functions. a Weed emergence control (Yb-Ym)/Yb

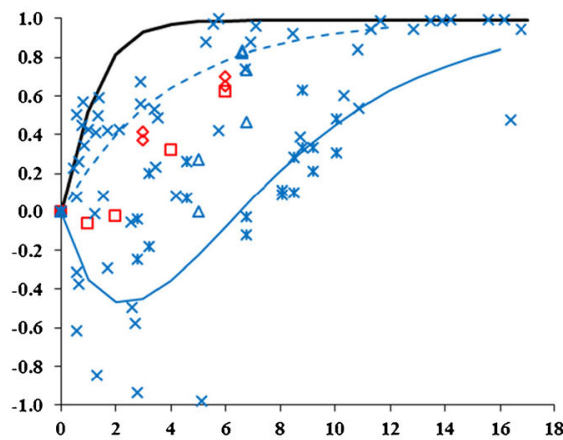

C

Weed biomass control $(\mathbf{Y b}-\mathbf{Y m}) / \mathbf{Y b}$

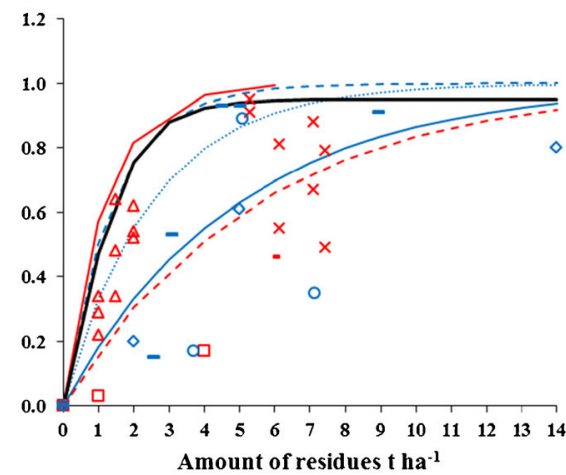

Fig. 7 Relative effect of surface crop residues on weed emergence and weed biomass control. Equations on weed emergence are from Teasdale and Mohler (2000) and correspond to a regression curve fitted to their observed data, with the solid line for the year $1996\left(r^{2}=0.43\right)$ and the dotted line for $1997\left(r^{2}=0.59\right)$. For weed biomass, curves in blue are from Radicetti et al. (2013) and correspond to regression curves fitted to their observed data $\left(r^{2}\right.$ not available). Solid line in red is an equation from Chauhan (2013) and corresponds to a regression curve fitted to his observed data $\left(r^{2}=0.99\right)$. Dotted line in red is from Ngwira et al.
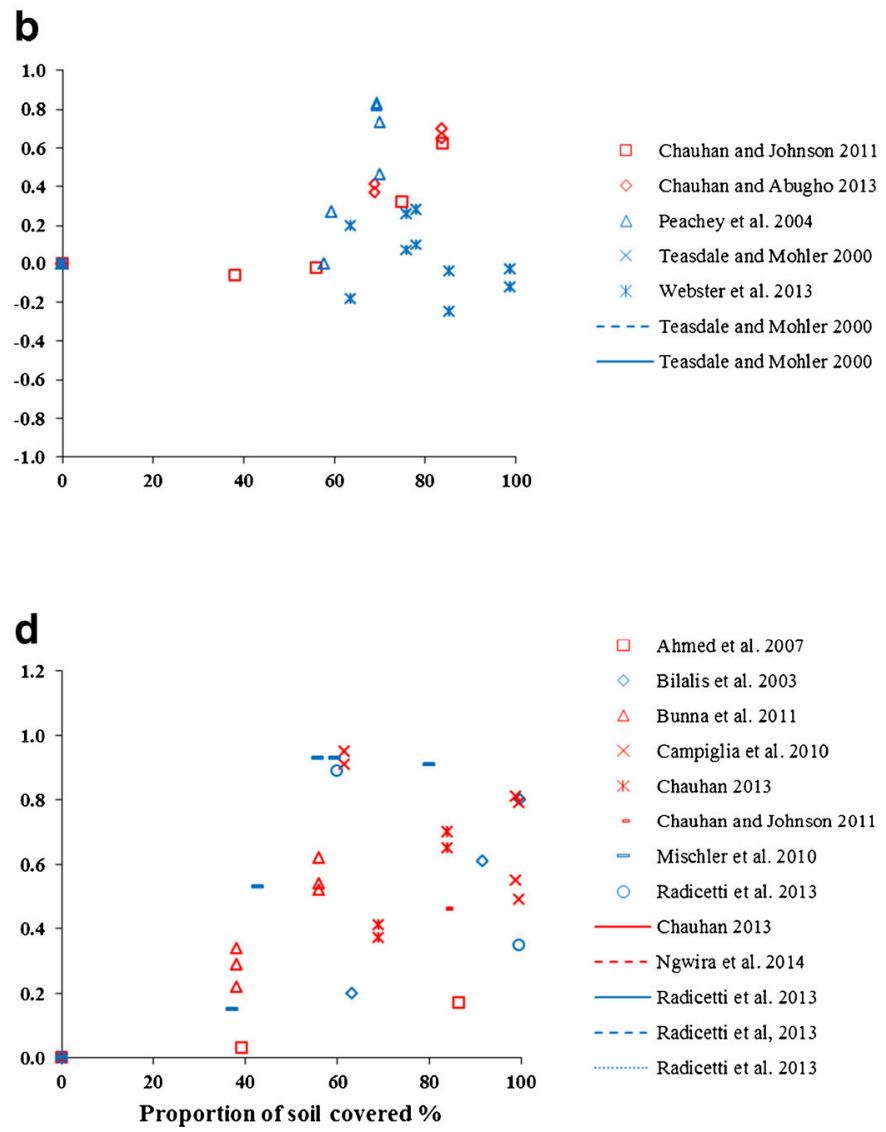

(2014) and corresponds to a boundary line fitted through their boundary points. Blue symbols are data from temperate zones and red symbols from tropical zones. Black curves are the boundary lines using the maximum likelihood methodology Data were from Ahmed et al. 2007, Bilalis et al. 2003, Bunna et al. 2011, Campiglia et al. 2010, Chauhan and Johnson 2011, Chauhan and Abugho 2013, Chauhan 2013, Mischler et al. 2010, Ngwira et al. 2014, Peachey et al. 2004, Radicetti et al. 2013, Teasdale and Mohler 2000, Webster et al. 2013. Ym: value of mulch soil, Yb: value of bare soil, see equations 2 and 3 


\section{a}

Meso- and macrofauna abundance $(\mathbf{Y m}-\mathbf{Y b}) / \mathbf{Y b}$

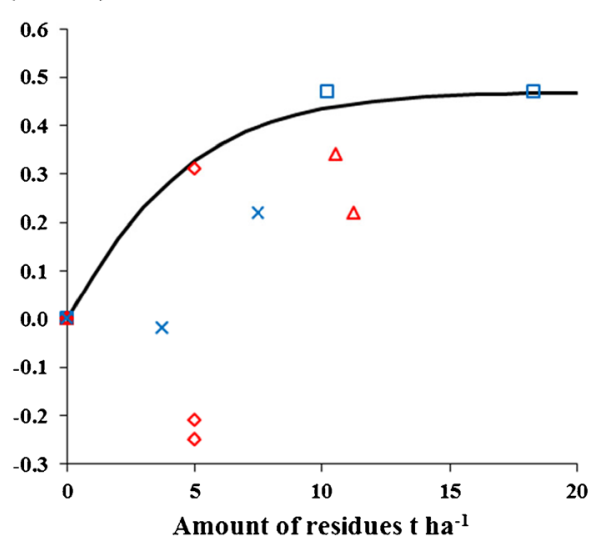

Fig. 8 Relative effect of surface crop residues on meso- and macrofauna abundance. Blue symbols are data from temperate zones and red symbols from tropical zones. Black curves are the boundary lines using the

\section{b}

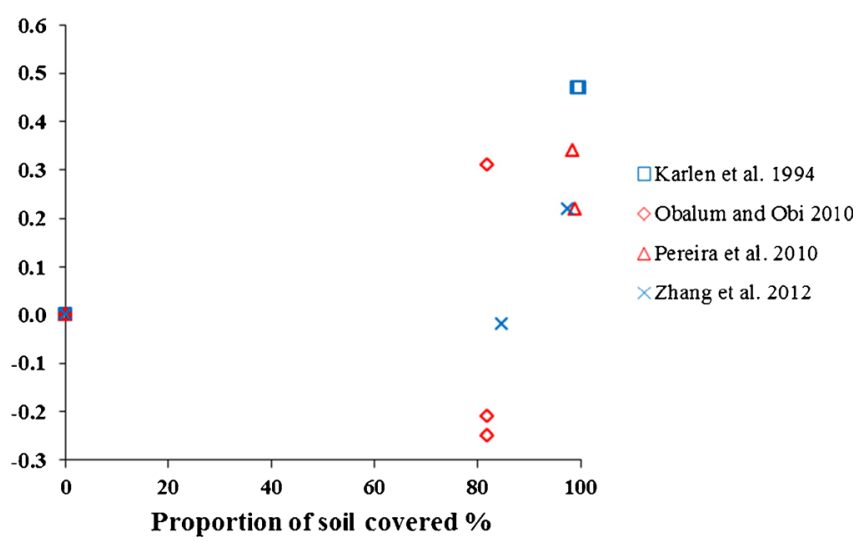

maximum likelihood methodology Data were from Karlen et al. 1994, Obalum and Obi 2010, Pereira et al. 2010, Zhang et al. 2012. Ym: value of mulch soil, $\mathrm{Yb}$ : value of bare soil, see equations 2 and 3

As shown in Fig. 9, the potential maximum effect of increasing amounts of surface crop residues on soil water evaporation control and soil nutrient availability was relatively low. Meso- and macrofauna abundance had a similarly weak response to increasing amounts of surface crop residues. On the other hand, the potential maximum effect of surface crop residues on soil water infiltration, water runoff and soil loss control was large. The threshold value of $2-3 \mathrm{t} \mathrm{ha}^{-1}$ of residues to reach the maximum effect on these agro-ecological functions predicted by the boundary lines is in accordance with the usual recommendation of a minimum soil cover of $30 \%$ in the practice of conservation agriculture (FAO 2015). Weed emergence and biomass control showed a maximum response from $4 \mathrm{tha}^{-1}$ of residues. The SOC stock increases with increasing amounts of mulch.

Our estimated amounts of surface crop residues from the boundary lines are low compared to the estimated $7 \mathrm{t}$ dry matter ha ${ }^{-1}$ recommended by Carvalho et al. (2016) to
$(\mathbf{Y m}-\mathbf{Y b}) / \mathbf{Y b}$

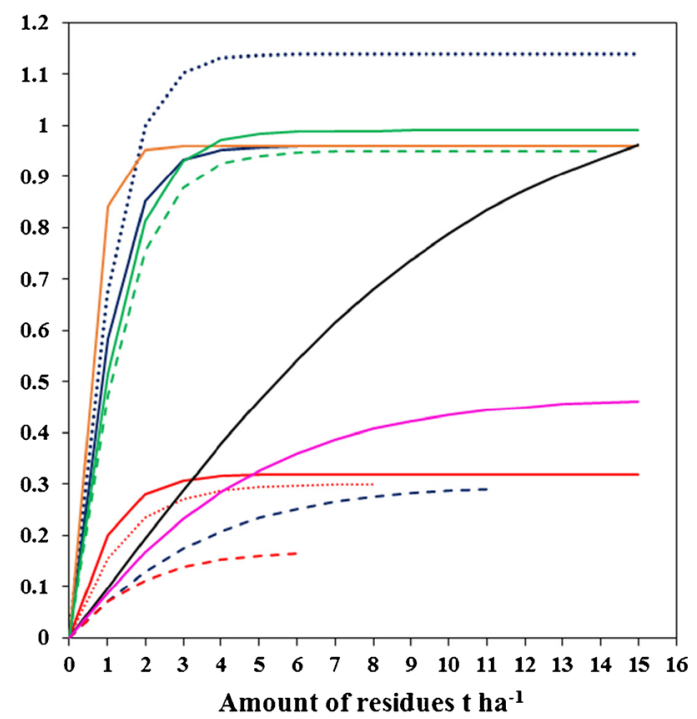

$(\mathbf{Y b}-\mathbf{Y m}) / \mathbf{Y b}$

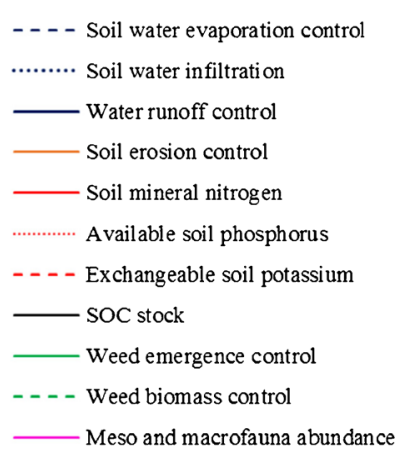

water runoff, soil erosion, weed emergence and weed biomass, which have negative impacts on crop production. $\mathrm{Ym}=$ agro-ecological function on mulched soil, $\mathrm{Yb}=$ agro-ecological function on bare soil. The curves are the boundary lines fitted from published data using the maximum likelihood methodology
Fig. 9 Maximum effect of surface crop residues in relation to their amount for a set of agro-ecological functions. Effect of residues was calculated as $(\mathrm{Ym}-\mathrm{Yb}) / \mathrm{Yb}$ for soil water infiltration, available N P K, SOC stock and meso- and macrofauna abundance, which have positive impacts on crop production; and $(\mathrm{Yb}-\mathrm{Ym}) / \mathrm{Yb}$ for soil water evaporation, 
preserve the maximum agronomic benefits of mulch. However, it should be noted that while the boundary lines represent the largest possible responses of agro-ecological functions to surface crop residues, typically a range of responses exists depending on other factors such as soil and climate conditions and the type of residue. Indeed, it is assumed that values below the boundary line are influenced by other independent variables or a combination of variables (Webb 1972) which limit the agro-ecological functions. The boundary lines represent the potential effects.

\section{Conclusions}

This systematic review of the agro-ecological functions of crop residue cover showed the overall beneficial effects of increasing the amounts of residues retained in the field as mulch. The amount of residue needed to have a significant effect compared to bare soil varied according to the agro-ecological function. Our analysis showed that more than $8 \mathrm{tha}^{-1}$ of residues was needed to decrease soil water evaporation by about $30 \%$ compared to a no-till bare soil. On the other hand, residue amounts of 2 to $3 \mathrm{t}$ dry matter $\mathrm{ha}^{-1}$ were sufficient to significantly improve soil water infiltration and control soil loss and water runoff. Soil nutrient (N, P and $\mathrm{K})$ availability and SOC stocks showed relatively weak responses to increased amounts of residues. The boundary line models for soil N, P and K supply were not significant. The estimated average annual gains in SOC were relatively low, with a mean of $0.38 \mathrm{t}$ $\mathrm{ha}^{-1}$ year $^{-1}$ of SOC for residue amounts of 4 to $5 \mathrm{t} \mathrm{ha}^{-1}$. The maximum effects of residue cover on weed emergence and biomass control were reached with $4 \mathrm{t} \mathrm{ha}^{-1}$ of residues or more, and corresponded to a decrease of more than $90 \%$ compared to bare soil. Soil meso- and macrofauna abundance showed a weak response to increasing residue levels. The maximum effect corresponded to an increase of $45 \%$ compared to no-till bare soil and was reached from $10 \mathrm{tha}^{-1}$ of residues. However, the predictive power of the derived functions should be considered with caution, particularly for soil water evaporation and soil nutrient availability, for which available data from the published literature were very limited.

The optimal amounts of surface residues in the practice of conservation agriculture will depend on the type of constraints to crop production which can be addressed with mulching. In high-input cropping systems, the role of surface residues may be more that of enhancing soil water processes, especially water runoff and soil erosion control, while in low-input systems, the role of mulching lies probably more in enhancing soil fertility through maintaining or increasing SOC stocks.
In reality, for many farmers leaving optimal levels of surface residues on their fields is problematic because of tradeoffs that exist with other uses. For example, small-scale farmers in sub-Saharan Africa tend to give precedence to using residues for livestock feed; not feeding crop residues to livestock would create too great a trade-off in livestock production on their farms. Likewise, commercial large-scale producers of maize in the USA or South America may find it economically more attractive to harvest maize residues for ethanol production and give preference to this rather than its use as mulch on the soil.

Acknowledgements We would like to thank FOFIFA (Centre National de Recherche Appliquée au Développement Rural), CIRAD (Centre de Coopération International en Recherche Agronomique pour le Développement), the ABACO project (Agroecology-based aggradationconservation agriculture) funded by the European Union and the CARIM project (Conservation agriculture in rice cropping systems in Madagascar: sustainability and adoption) funded by the Agropolis Foundation, for financial support.

\section{References}

Ahmed ZI, Ansar M, Iqbal M, Minhas NM (2007) Effect of planting geometry and mulching on moisture conservation, weed control and wheat growth under rainfed conditions. Pakistan J Bot 39: $1189-1195$

Anzalone A, Cirujeda A, Aibar J et al (2010) Effect of biodegradable mulch materials on weed control in processing tomatoes. Weed Technol 24:369-377. doi:10.1614/WT-09-020.1

Aulakh MS, Doran JW, Walters DT et al (1991) Crop residue type and placement effects on denitrification and mineralization. Soil Sci Soc Am J 1025:1020-1025

Balwinder-Singh, Eberbach PL, Humphreys E, Kukal SS (2011) The effect of rice straw mulch on evapotranspiration, transpiration and soil evaporation of irrigated wheat in Punjab, India. Agric Water Manag 98:1847-1855. doi:10.1016/j.agwat.2011.07.002

Benech-Arnold R, Sanchez R, Forcella F et al (2000) Environmental control of dormancy in weed seed banks in soil.pdf. Field Crop Res 67:105-122

Beri V, Sidhu BS, Bahl GS, Bhat AK (1995) Nitrogen and phosphorus transformations as affected by crop residue management practices and their influence on crop yield. Soil Use Manag 11:51-54. doi:10. 1111/j.1475-2743.1995.tb00496.x

Bertol I, Engel FL, Mafra AL et al (2007) Phosphorus, potassium and organic carbon concentrations in runoff water and sediments under different soil tillage systems during soybean growth. Soil Tillage Res 94:142-150. doi:10.1016/j.still.2006.07.008

Bilalis D, Sidiras N, Economou G, Vakali C (2003) Effect of different levels of wheat straw soil surface coverage on weed flora in Vicia faba crops. J Agron Crop Sci 189:233-241

Blanchart E, Bernoux M, Sarda X et al (2007) Effect of direct seeding mulch-based systems on soil carbon storage and macrofauna in Central Brazil. Agric Conspec Sci 72:81-87

Blanco-Canqui H, Lal R (2007a) Impacts of long-term wheat straw management on soil hydraulic properties under no-tillage. Soil Sci Soc Am J 71:1166-1173. doi:10.2136/sssaj2006.0411

Blanco-Canqui H, Lal R (2007b) Soil structure and organic carbon relationships following 10 years of wheat straw management in no-till. Soil Tillage Res 95:240-254. doi:10.1016/j.still.2007.01.004 
Blanco-Canqui H, Lal R (2009) Crop Residue Removal Impacts on Soil Productivity and Environmental Quality. Plant Sci 37-41. doi:10. 1080/07352680902776507

Brévault T, Bikay S, Maldès JM et al (2007) Impact of a no-till with mulch soil management strategy on soil macrofauna communities in a cotton cropping system. Soil Tillage Res 97:140-149. doi:10. 1016/j.still.2007.09.006

Buhler DT, Mester C, Kohler KA (1996) The effect of maize residues and tillage on emergence of Setaria faberi Abutilon theophrasti, Amaranthus retroflexus and Chenopodium album. Weed Res 36: 153-165. doi:10.1111/j.1365-3180.1996.tb01811.x

Bunna S, Sinath P, Makara O et al (2011) Effects of straw mulch on mungbean yield in rice fields with strongly compacted soils. Field Crop Res 124:295-301. doi:10.1016/j.fcr.2011.06.015

Caamal-Maldonado JA, Jiménez-Osornio JJ, Torres-Barragán A, Anaya AL (2001) The use of allelopathic legume cover and mulch species for weed control in cropping systems. Agron J 93:27-36

Calonego JC, Rosolem CA (2013) Phosphorus and potassium balance in a corn-soybean rotation under no-till and chiseling. Nutr Cycl Agroecosyst 96:123-131. doi:10.1007/s10705-013-9581-x

Campbell CA, Mcconkey BG, Zenlner RP et al (1996a) Long-term effects of tillage and crop rotations on soil organic $\mathrm{C}$ and total $\mathrm{N}$ in a clay soil in southwestern Saskatchewan. Can J Soil Sci 76:395-401

Campbell CA, Mcconkey BG, Zentner RP et al (1996b) Tillage and crop rotation effects on soil organic $\mathrm{C}$ and $\mathrm{N}$ in a coarse-textured Typic Haploboroll in southwestern Saskatchewan. Soil Tillage Res 37:314

Campiglia E, Caporali F, Radicetti E, Mancinelli R (2010) Hairy vetch ( Vicia villosa Roth.) cover crop residue management for improving weed control and yield in no-tillage tomato (Lycopersicon esculentum Mill.) production. Eur J Agron 33:94-102. doi:10. 1016/j.eja.2010.04.001

Campiglia E, Radicetti E, Mancinelli R (2012) Weed control strategies and yield response in a pepper crop (Capsicum annuum $\mathrm{L}$.) mulched with hairy vetch (Vicia villosa Roth.) and oat (Avena sativa L.) residues. Crop Prot 33:65-73. doi:10.1016/j.cropro.2011.09.016

Carvalho JLN, Nogueirol RC, Menandro LMS, et al (2016) Agronomic and environmental implications of sugarcane straw removal : a major review. GCB Bioenergy 1-16. doi: 10.1111/gcbb.12410

Cattan P, Cabidoche Y-M, Lacas J-G, Voltz M (2006) Effects of tillage and mulching on runoff under banana (Musa spp.) on a tropical Andosol. Soil Tillage Res 86:38-51. doi:10.1016/j.still.2005.02.002

Chauhan BS (2013) Seed germination ecology of feather lovegrass [Eragrostis tenella (L.) Beauv. Ex Roemer \& J.A. Schultes]. PLoS One 8:e79398. doi:10.1371/journal.pone.0079398

Chauhan BS, Abugho SB (2013) Effect of crop residue on seedling emergence and growth of selected weed species in a sprinkler-irrigated zero-till dry-seeded rice system. Weed Sci 61:403-409. doi:10. 1614/WS-D-12-00147.1

Chauhan BS, Johnson DEE (2011) Ecological studies on Echinochloa crusgalli and the implications for weed management in direct-seeded rice. Crop Prot 30:1385-1391. doi:10.1016/j.cropro.2011.07.013

Chauhan BS, Singh RG, Mahajan G et al (2012) Ecology and management of weeds under conservation agriculture: a review. Crop Prot 38:57-65. doi:10.1016/j.cropro.2012.03.010

Clapp CE, Allmaras RR, Layese MF et al (2000) Soil organic carbon and $13 \mathrm{C}$ abundance as related to tillage, crop residue, and nitrogen fertilization under continuous corn management in Minnesota. Soil Tillage Res 55:127-142. doi:10.1016/S0167-1987(00)00110-0

Corbeels M, Scopel E, Cardoso A et al (2006) Soil carbon storage potential of direct seeding mulch-based cropping systems in the Cerrados of Brazil. Glob Chang Biol 12:1773-1787. doi:10.1111/j.13652486.2006.01233.x

Dickey EC, Shelton DP, Jasa PJ, Peterson T (1985) Soil Erosion from Tillage Systems Used in Soybean and Corn Residues in Soybean and Corn Residues. Trans Am Soc Agric Eng 28:1124-1130
Dunne T, Zhang W, Aubry BF (1991) Effects of rainfall, vegetation, and microtopography on infiltration and runoff. Water Resour Res 27: 2271-2285

FAO (2015) Conservation agriculture. http://www.fao.org/ag/ca/la.html. Accessed 16 Feb 2017

Feng Y, Liu Q, Tan C et al (2014) Water and nutrient conservation effects of different tillage treatments in sloping fields. Arid Land Res Manag 28:14-24. doi:10.1080/15324982.2013.811446

Findeling A, Ruy S, Scopel E (2003) Modeling the effects of a partial residue mulch on runoff using a physically based approach. J Hydrol 275:49-66. doi: 10.1016/S0022-1694(03)00021-0

Gangwar KS, Singh KK, Sharma SK, Tomar OK (2006) Alternative tillage and crop residue management in wheat after rice in sandy loam soils of Indo-Gangetic plains. Soil Tillage Res 88:242-252

Gava R, de Freitas PSL, de Faria RT et al (2013) Soil water evaporation under densities of coverage with vegetable residue. Eng Agric 33: 89-98. doi:10.1590/S0100-69162013000100010

Giller KE, Witter E, Corbeels M, Tittonell P (2009) Conservation agriculture and smallholder farming in Africa: the heretics' view. Field Crop Res 114:23-34. doi:10.1016/j.fcr.2009.06.017

Gilley JE, Finkner SC, Varvel GE (1986) Runoff and erosion as affected by sorghum and soybean residue. Trans Am Soc Agric Eng 29: $1605-1610$

Govaerts B, Sayre KD, Ceballos-Ramirez JM et al (2006) Conventionally tilled and permanent raised beds with different crop residue management: effects on soil C and N dynamics. Plant Soil 280:143-155. doi:10.1007/s11104-005-2854-7

Govaerts B, Mezzalama M, Unno Y et al (2007) Influence of tillage, residue management, and crop rotation on soil microbial biomass and catabolic diversity. Appl Soil Ecol 37:18-30. doi:10.1016/j. apsoil.2007.03.006

Gregory JM (1982) Soil cover prediction with various amounts and types of crop residue. Trans ASABE 25:1333-1337

Halpern MT, Whalen JK, Madramootoo C a. (2010) Long-term tillage and residue management influences soil carbon and nitrogen dynamics. Soil Sci Soc Am J 74:1211. doi:10.2136/sssaj2009. 0406

Haynes RJ, Mokolobate MS (2001) Amelioration of Al toxicity and P deficiency in acid soils by additions of organic residues: a critical review of the phenomenon and the mechanisms involved. Nutr Cycl Agroecosyst 59:47-63. doi:10.1023/A:1009823600950

Hendriksen NB (1990) Leaf litter selection by detritivore and geophagous earthworms. Biol Fertil Soils 10:17-21. doi:10.1007/BF00336119

Hobbs PR (2007) Conservation agriculture: what is it and why is it important for future sustainable food production? J Agric Sci 145:127137. doi:10.1017/S0021859607006892

Hooker BA, Morris TF, Peters R, Cardon ZG (2005) Long-term effects of tillage and corn stalk return on soil carbon dynamics. Soil Sci Soc Am J 69:188-196

Iqbal M, Ul-Hassan A, van Es HM (2011) Influence of residue management and tillage systems on carbon sequestration and nitrogen, phosphorus, and potassium dynamics of soil and plant and wheat production in semi-arid region. Soil Sci Plant Anal 42:528-547. doi: 10.1080/00103624.2011.546929

Jagadamma S, Lal R (2010) Distribution of organic carbon in physical fractions of soils as affected by agricultural management. Biol Fertil Soils 46:543-554. doi: 10.1007/s00374-010-0459-7

Jordán A, Zavala LM, Gil J (2010) Effects of mulching on soil physical properties and runoff under semi-arid conditions in southern Spain. Catena 81:77-85. doi:10.1016/j.catena.2010.01.007

Kahlon MS, Lal R, Ann-Varughese M (2012) Twenty two years of tillage and mulching impacts on soil physical characteristics and carbon sequestration in Central Ohio. Soil Tillage Res 126:151-158

Karlen DL, Wollenhaupt NC, Erbach DC et al (1994) Crop residue effects on soil quality following 10-years of no-till corn. Soil Tillage Res $31: 149-167$ 
Kato-Noguchi H, Kosemura S, Yamamura S et al (1994) Allelopathy of oats. I. Assessment of allelopathic potential of extract of oat shoots and identification of an allelochemical. J Chem Ecol 20:309-314. doi:10.1007/BF02064439

Kladivko EJ (2001) Tillage systems and soil ecology. Soil Tillage Res 61: 61-76. doi:10.1016/S0167-1987(01)00179-9

Lal R (1984) Mulch requirements for erosion control with the no-till system in the tropics: a review. In: D.E. W (ed) Challenges in African Hydrology and Water Resources, Proceedings of the Harare Symposium. International Association of Hydrological Sciences; IAHS-AISH Publication 144, Washington, DC, USA, pp 475-484

Lal R (1997) Mulching effects on runoff, soil erosion, and crop response on alfisols in western Nigeria. J Sustain Agric 11:135-154. doi:10. 1300/J064v11n02_10

Lal R (1998) Soil quality changes under continuous cropping for seventeen seasons of an Alfisol in western Nigeria. Land Degrad Dev 9: 259-274. doi:10.1002/(SICI)1099-145X(199805/06)9:3<259:: AID-LDR290>3.0.CO;2-V

Lal R (2004) Soil carbon sequestration impacts on global climate change and food security. Science (80- ) 304:1623-1627. doi: 10.1126/ science. 1097396

Lal R (2008) Managing soil water to improve rainfed agriculture in India. J Sustain Agric 32:51-75. doi:10.1080/10440040802121395

Lal R (2009) Soil quality impacts of residue removal for bioethanol production. Soil Tillage Res 102:233-241. doi:10.1016/j.still.2008.07. 003

Lenka NK, Lal R (2013) Soil aggregation and greenhouse gas flux after 15 years of wheat straw and fertilizer management in a no-till system. Soil Tillage Res 126:78-89. doi:10.1016/j.still.2012.08.011

Liu T, Chen X, Hu F et al (2016) Carbon-rich organic fertilizers to increase soil biodiversity: evidence from a meta-analysis of nematode communities. Agric Ecosyst Environ 232:199-207. doi:10.1016/j. agee.2016.07.015

Lorenz K, Lal R, Shipitalo MJ (2008) Chemical stabilization of organic carbon pools in particle size fractions in no-till and meadow soils. Biol Fertil Soils 44:1043-1051. doi: 10.1007/s00374-008-0300-8

Lu, Y.-C.C., Watkins, K.B., Teasdale, J.R., Abdul-baki, A. a. (2000) Cover Crops in Sustainable Food Production. Food Rev. Int. 16, 121-157. doi:10.1081/FRI-100100285

Lupwayi NZ, Clayton GW, O'Donovan JT et al (2006) Potassium release during decomposition of crop residues under conventional and zero tillage. Can J Soil Sci 86:473-481

Macena Da Silva FAM, Pinto HS, Scopel E et al (2006) Water fluxes in maize, millet and soybean plant-residue mulches used in direct seeding. Pesqui Agropecu Bras 41:717-724. doi:10.1590/S0100204X2006000500001

Mannering J V., Meyer LD (1963) The Effects of Various Rates of Surface Mulch on Infiltration and Erosion. Soil Sci Soc Am J 27: 84-86. doi:10.2136/sssaj1963.03615995002700010029x

Milne AE, Ferguson RB, Lark RM (2006) Estimating a boundary line model for a biological response by maximum likelihood. Ann Appl Biol 149:223-234. doi:10.1111/j.1744-7348.2006.00086.x

Mischler RA, Curran WS, Duiker SW, Hyde JA (2010) Use of a rolledrye cover crop for weed suppression in no-till soybeans. Weed Technol 24:253-261. doi:10.1614/WT-D-09-00004.1

Moher D, Liberati A, Tetzlaff J, et al (2009) Preferred Reporting Items for Systematic Reviews and Meta-Analyses : The PRISMA Statement. Plos Med. doi: 10.1371/journal.pmed.1000097

Naudin K, Scopel E, Andriamandroso ALH et al (2012) Trade-offs between biomass use and soil cover. The case of rice-based cropping systems in the Lake Alaotra region of Madagascar. Exp Agric 48: 194-209. doi:10.1017/S001447971100113X

Nawaz A, Lal R, Shrestha RK, Farooq M (2016) Mulching affects soil properties and greenhouse gas emissions under long-term no-till and plough-till systems in alfisol of Central Ohio. L Degrad Dev 681: 673-681. doi:10.1002/ldr.2553

Ngwira AR, Aune JB, Thierfelder C (2014) On-Farm Evaluation of the Effects of the Principles and Components of Conservation Agriculture on Maize Yield and Weed Biomass in Malawi. Exp Agric 50:591-610. doi: 10.1017/S001447971400009X

Nyakatawa E, Jakkula V (2007) Soil erosion estimation in conservation tillage systems with poultry litter application using RUSLE 2.0 model. Soil Tillage 94:410-419. doi:10.1016/j.still.2006.09.003

Obalum SE, Obi ME (2010) Physical properties of a sandy loam Ultisol as affected by tillage-mulch management practices and cropping systems. Soil Tillage Res 108:30-36. doi:10.1016/j.still.2010.03. 009

Oldeman LR (1998) Soil degradation: a threat to food security? In: International soil reference and information centre. Wageningen

Panachuki E, Bertol I, Sobrinho TA, et al (2011) Soil and water loss and water infiltration in red latosol under different management systems. Rev Bras Cienc do Solo 35:1777-1786. doi:10.1590/S010006832011000500032

Peachey RE, William RD, Mallory-smith C (2004) Effect of no-till or conventional planting and cover crops residues on weed emergence in vegetable row crop 1 . Weed Technol 18:1023-1030. doi:10.1614/ WT-03-205R

Peel MC, Finlayson BL, McMahon TA (2007) Updated world map of the Köppen-Geiger climate classification. Hydrol Earth Syst Sci 11: 1633-1644. doi:10.1127/0941-2948/2006/0130

Pereira JL, Picanço MC, Pereira EJG et al (2010) Influence of crop management practices on bean foliage arthropods. Bull Entomol Res 100:679-688. doi:10.1017/S0007485310000039

Pradhan PR, Pandey RN, Behera UK et al (2011) Tillage and crop residue management practices on crop productivity, phosphorus uptake and forms in wheat (Triticum aestivum)-based cropping systems. Indian J Agric Sci 81:1168-1173

Radicetti E, Mancinelli R, Campiglia E (2013) Impact of managing cover crop residues on the floristic composition and species diversity of the weed community of pepper crop (Capsicum annuum L.) Crop Prot 44:109-119. doi:10.1016/j.cropro.2012.10.017

Rasmussen PE, Collins HP (1991) Long-term impacts of tillage, fertilizer, and crop residue on soil organic matter in temperate semiarid regions. Adv Agron 45:93-134. doi: 10.1016/S0065-2113(08)60039-

Rohatgi A (2015) WebPlotDigitizer 3.8. http://arohatgi.info/ WebPlotDigitizer. Accessed 1 Feb 2016

Rosolem CA, Calonego JC, Foloni JSS (2005) Potassium leaching from millet straw as affected by rainfall and potassium rates. Commun Soil Sci Plant Anal 36:1063-1074. doi:10.1081/CSS-200050497

Rosolem CA, Dos Santos FP, Foloni JSS et al (2006) Soil potassium as affected by fertilization over the millet straw and simulated rain. Pesqui Agropecu Bras 41:1033-1040

Ruy S, Findeling A, Chadoeuf J (2006) Effect of mulching techniques on plot scale runoff: FDTF modeling and sensitivity analysis. J Hydrol 326:277-294. doi:10.1016/j.jhydrol.2005.11.003

Sainju UM, Singh BP, Whitehead WF, Wang S (2007) Accumulation and crop uptake of soil mineral nitrogen as influenced by tillage, cover crops, and nitrogen fertilization. Agron J 99:682-691. doi:10.2134/ agronj2006.0177

Sato S, Comerford NB (2005) Influence of soil pH on inorganic phosphorus sorption and desorption in a humid Brazilian Ultisol. Rev Bras Cienc do Solo 29:685-694. doi:10.1590/S0100-06832005000500004

Schneider EC, Gupta SC (1985) Corn emergence as influenced by soil temperature, matric potential, and aggregate size distribution. Soil Sci Soc Am J 49:415-422. doi:10.2136/sssaj1985. 03615995004900020029x

Scopel E, Da Silva FAMM, Corbeels M et al (2004) Modelling crop residue mulching effects on water use and production of maize 
under semi-arid and humid tropical conditions. Agronomie 24:383395. doi:10.1051/agro:2004029

Scopel E, Findeling A, Chavez Guerra E et al (2005) Impact of direct sowing mulch-based cropping systems on soil carbon, soil erosion and maize yield. Agron Sustain Dev 25:425-432. doi:10.1051/agro: 2005041

Scopel E, Triomphe B, Affholder F et al (2013) Conservation agriculture cropping systems in temperate and tropical conditions, performances and impacts. A review. Agron Sustain Dev 33:113-130. doi:10.1007/s13593-012-0106-9

Sharratt B, Zhang M, Sparrow S (2006) Twenty years of conservation tillage research in subarctic Alaska. Soil Tillage Res 91:82-88. doi: 10.1016/j.still.2006.01.010

Sidiras N, Roth CH (1987) Infiltration measurements with double-ring infiltrometers and a rainfall simulator under different surface conditions on an Oxisol. Soil Tillage Res 9:161-168

Singh BB, Jones J. (1976) Phosphorous Sorption and Desorption Characteristics of Soil as Affected by Organic Residues. Soil Sci Soc Am J 40:389-394. doi:10.2136/sssaj 1976 . $03615995004000030025 x$

Smith GD, Coughlan KJ, Yule DF et al (1992) Soil management options to reduce runoff and erosion on a hardsetting alfisol in the semi-arid tropics. Soil Tillage Res 25:195-215

Spedding TA, Hamel C, Mehuys GR, Madramootoo CA (2004) Soil microbial dynamics in maize-growing soil under different tillage and residue management systems. Soil Biol Biochem 36:499-512. doi:10.1016/j.soilbio.2003.10.026

Steiner JL, Schomberg HH, Unger PW, Cresap J (2000) Biomass and residue cover relationships of fresh and decomposing small grain residue. Soil Sci Soc Am J 64:2109-2114

Stinner BR (1990) Arthropods and other invertebrates in conservationtillage agriculture. Annu Rev Entomol 35:299-318. doi:10.1146/ annurev.en.35.010190.001503

Stumborg M, Townley-Smith L, Coxworth E, East S (1996) Sustainability and economic issues for cereal crop residue export. Can J Plant Sci 76:669-673

Swanson S, Wilhelm W (1996) Planting Date and Residue Rate Effects on Growth , Partitioning, and Yield of Corn. Agron J 88:205-210

Teasdale JR, Mohler CL (1993) Light transmittance, soil temperature, and soil moisture under residue of hairy vetch and rye. Agron J 85:673380. doi:10.2134/agronj1993.00021962008500030029x

Teasdale JR, Mohler CL (2000) The quantitative relationship between weed emergence and the physical properties of mulches. Weed Sci 48:385-392. doi:10.1614/0043-1745(2000)048[0385:TQRBWE]2. $0 . \mathrm{CO} ; 2$

Teasdale JR, Beste CE, Potts WE (1991) Response of weed to tillage and cover crop residue. Weed Sci. Soc. Am. 39:195-199

TerAvest D, Carpenter-Boggs L, Thierfelder C, Reganold JP (2015) Crop production and soil water management in conservation agriculture, no-till, and conventional tillage systems in Malawi. Agric Ecosyst Environ 212:285-296. doi:10.1016/j.agee.2015.07.011

Tian G, Brussaard L, Kang BT (1993) Biological effects of plant residues with contrasting chemical compositions under humid tropical conditions: effects on soil fauna. Soil Biol Biochem 25:731-737

Törnqvist L, Vartia P, Vartia YO, et al (1985) How Should Relative Changes Be Measured? Am Stat 39:37-41. doi:10.1080/ 00031305.1985.10479385

Turmel MM-S, Speratti A, Baudron F et al (2014) Crop residue management and soil health: a systems analysis. Agric Syst 134:6-16. doi: 10.1016/j.agsy.2014.05.009

Verhulst N, Kienle F, Sayre KD et al (2010) Soil quality as affected by tillage-residue management in a wheat-maize irrigated bed planting system. Plant Soil 340:453-466. doi:10.1007/s11104-010-0618-5

Vollmer ER, Creamer N, Reberg-Horton C, Hoyt G (2010) Evaluating cover crop mulches for no-till organic production of onions. Hortscience 45:61-70

Wang JB, Chen ZH, Chen LJ et al (2011) Surface soil phosphorus and phosphatase activities affected by tillage and crop residue input amounts. Plant Soil Environ 57:251-257

Webb RA (1972) Use of the boundary line in the analysis of biological data. J Hortic Sci 47:309-319. doi:10.1080/00221589.1972. 11514472

Webster TM, Scully BT, Grey TL, Culpepper AS (2013) Winter cover crops influence Amaranthus palmeri establishment. Crop Prot 52: 130-135. doi:10.1016/j.cropro.2013.05.015

Wei K, Chen Z, Zhu A et al (2014) Application of 31P NMR spectroscopy in determining phosphatase activities and $\mathrm{P}$ composition in soil aggregates influenced by tillage and residue management practices. Soil Tillage Res 138:35-43. doi:10.1016/j.still.2014.01.001

Weston LA (1997) Utilization of Allelopathy for Weed Management in Agroecosystems. Int Inf Syst Agric Sci Technol 88:860-866

Wilhelm W (2004) Crop and Soil Productivity Response to Corn Residue Removal : A Literature Review. Agronomy Journal, 96(1), 1-17

Willmott CJ, Robeson SM, Matsuura K (2012) A refined index of model performance. Int J Climatol 32:2088-2094. doi:10.1002/joc.2419

Wilson GV, Dabney SM, McGregor KC, Barkoll BD (2004) Tillage and residue effects on runoff and erosion dynamics. Trans Am Soc Agric Eng 47:119-128

Woyessa YE, Bennie TP (2004) Factors affecting runoff and soil loss under simulated rainfall on a sandy Bainsvlei Amalia soil. S Afr J Plant Soil 21:203-208. doi:10.1080/02571862.2004.10635050

Zerner MC, Gill GS, Vandeleur RK (2008) Effect of height on the competitive ability of wheat with oats. Agron J 100:1729-1734

Zhang X, Li Q, Zhu A et al (2012) Effects of tillage and residue management on soil nematode communities in North China. Ecol Indic 13: 75-81. doi:10.1016/j.ecolind.2011.05.009 